\title{
Seasonal changes in pore water pressure in a grass-covered cut slope in London Clay
}

\author{
J. A. SMETHURST*, D. CLARKE* and W. POWRIE*
}

In temperate European climates, the season of peak water demand by vegetation (summer) is out of phase with the season of greatest rainfall (winter). This results in seasonal fluctuations in soil water content and, in clay soils, associated problems of shrinking and swelling that can in turn contribute to strain-softening and progressive slope failure. This paper presents field measurements of seasonal moisture content and pore water pressure changes within the surface drying zone of a cut slope in the London Clay at Newbury, Berkshire, UK. A climate station was installed at the site to measure the parameters needed to determine specific plant evapotranspiration. This information was used to carry out a water balance calculation to estimate the year-round soil moisture deficit caused by the vegetation. The calculated soil moisture deficit matches reasonably closely the field measurements of soil drying. The field measurements of seasonal changes in pore water pressure and suction are linked quantitatively to the measured changes in water content using the soil water characteristic curve for the London Clay. The suctions generated by the light vegetation cover at Newbury were found not to persist into the winter and early spring.

KEYWORDS: clays; field instrumentation; monitoring; pore pressures; slopes; suction
Dans les zones européennes de climat tempéré, la période de demande d'approvisionnement en eau la plus importante pour la végétation ne correspond pas à la saison de pluviosité la plus forte (hiver). Il en résulte des fluctuations du taux d'humidité dans le sol, et, pour les terrains argileux, des problèmes associés de gonflement et rétrécissement qui peuvent, à leur tour, contribuer à un écrouissage négatif et une fracture progressive du versant. Cet article présente des expérimentations réalisées in situ pour mesurer le taux d'humidité et les variations de pression hydrique interstitielle saisonniers à l'intérieur de la zone d'assèchement de la surface d'un versant découpé dans le London Clay à Newbury, dans le Berkshire, au Royaume-Uni. Une station climatologique a été installée sur le site afin de relever les paramètres nécessaires pour déterminer l'évapotranspiration végétale spécifique. Ces informations ont été utilisées pour calculer le bilan hydrique et estimer ainsi, sur une année, le déficit hydrique que la végétation provoque au niveau du sol. Les résultats de ces calculs en matière de déficit hydrique montrent une corrélation raisonnablement étroite avec les mesures de l'assèchement du sol in situ. Pour la succion et la pression interstitielle de l'eau, les mesures des variations saisonnières, relevées in situ, sont qualitativement liées aux variations de teneur en eau obtenues à l'aide de la courbe caractéristique d'humidité du sol pour le London Clay. Nous avons pu observer que les succions produites par la légère couverture végétale à Newbury ne persistent pas en hiver et au début du printemps.

\section{BACKGROUND}

It is well known that plants can influence the engineering performance of slopes. Beneficial effects include root reinforcement, generation of pore water suctions, buttressing and arching. Detrimental effects include loading of the upper part of the slope and loading associated with uprooting or overturning (Barker, 1986; Coppin \& Richards, 1990). In temperate European climates, the season of peak water demand by vegetation (summer) is out of phase with the season of greatest rainfall (winter). This results in seasonal fluctuations in soil moisture content and associated problems of shrinking and swelling in clay soils that can in turn lead to major serviceability problems. For example, large volume losses due to soil shrinkage in vegetated railway embankments can cause significant distortion of railway tracks (Andrei, 2000).

In clays, the cyclic changes in water content will result in corresponding cyclic changes in pore water pressure and hence effective stress. In a conventional static slope stability

Manuscript received 19 May 2005; revised manuscript accepted 18 July 2006.

Discussion on this paper closes on 2 April 2007, for further details see p.ii.

* School of Civil Engineering and the Environment, University of Southampton, UK. analysis in which worst-case pore pressure conditions are considered, suctions generated by vegetation will have a beneficial effect only if they are carried through into winter and early spring. Mature trees growing in low-permeability clays have been demonstrated to generate sufficiently large suctions in the summer to prevent full re-wetting of the soil in winter and spring (Biddle, 1983, 1998; Driscoll, 1983); however, the suctions generated by light shrub and/or grass cover are rarely sustained through the winter period (Croney, 1977; Greenwood et al., 2001, 2004). Furthermore, there is recent evidence from both centrifuge model tests and numerical analyses of clay slopes that cyclic stresses thought to be representative of those induced by vegetation can cause strain-softening to occur, starting from the toe of the slope (Nyambayo et al., 2004; Take \& Bolton, 2004; O'Brien et al., 2004; Vaughan et al., 2004). Over a period of several years, these cycles of pore pressure and effective stress can result in progressive failure.

Knowledge of the effects of climate and vegetation on pore water pressures is important for the validation of numerical models of slope stability that attempt to take into account the complex interactions between climate, vegetation and the ground. Such models are essential if the cyclic changes in effective stress that lead potentially to progressive failure and the influence of climate change on longterm slope stability are to be understood. There have been 
several studies of pore water pressures in vegetated clay infrastructure slopes (Walbancke, 1976; Anderson \& Kneale, 1980; Crabb et al., 1987; Ridley et al., 2004a, 2004b), including recent field investigations to assess the impact of different types of vegetation (Greenwood et al., 2001; MacNeil et al., 2001). However, few of these have tried to link closely the observed changes in pore water pressure to a full soil moisture deficit calculation based on vegetation properties and climatic parameters, as advocated by Blight (1997).

This paper describes and analyses the results of a field study carried out to quantify the hydrological environment and pore water pressures in a cut slope in London Clay. Data were collected over a complete winter/summer cycle, including a wet winter (2002) followed by an exceptionally dry summer (2003). A full soil water balance is developed, and linked to the observed pore water pressures.

\section{SITE DESCRIPTION AND SOIL CHARACTERISTICS}

A cutting on the A34 Newbury bypass in southern England (Fig. 1; OS grid reference SU455652) was chosen for the study owing to its accessibility and relatively uniform soil conditions and vegetation characteristics (mainly grass). The instrumented slope is east facing, $8 \mathrm{~m}$ high and $28 \mathrm{~m}$ long (Fig. 2). The cutting was constructed in 1997, and is entirely within the London Clay. The London Clay at the site is about $20 \mathrm{~m}$ thick, highly weathered to a depth of about $2.5 \mathrm{~m}$ below original ground level, and underlain by Lambeth Group deposits and the Upper Chalk. After the cutting was excavated, up to $0.4 \mathrm{~m}$ of topsoil was placed over the cut London Clay surface to facilitate the planting of vegetation on the slope. A gravel fin drain approximately $600 \mathrm{~mm}$ deep, $4 \mathrm{~m}$ from the toe of the slope, was installed to drain the road subbase. The fin drain connects at intervals into a sealed carrier drain that outfalls to the south of the cutting, and to which the road gullies are also connected. A cross-section through the slope is shown in Fig. 3.

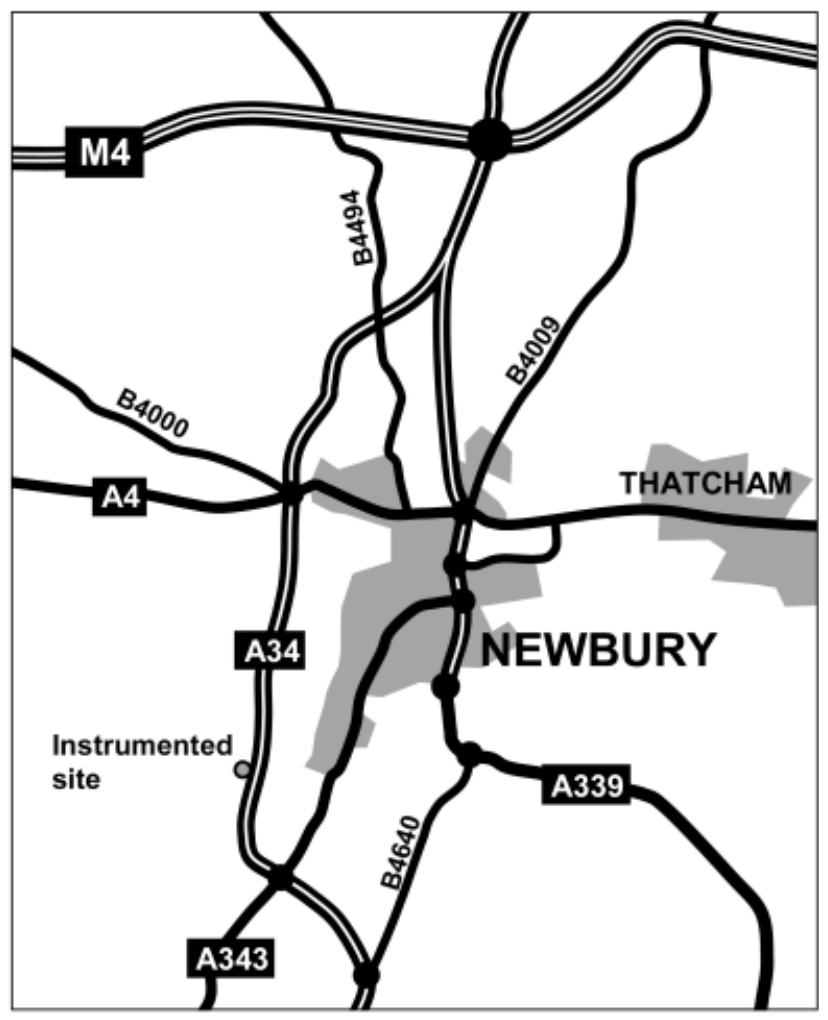

Fig. 1. Location map

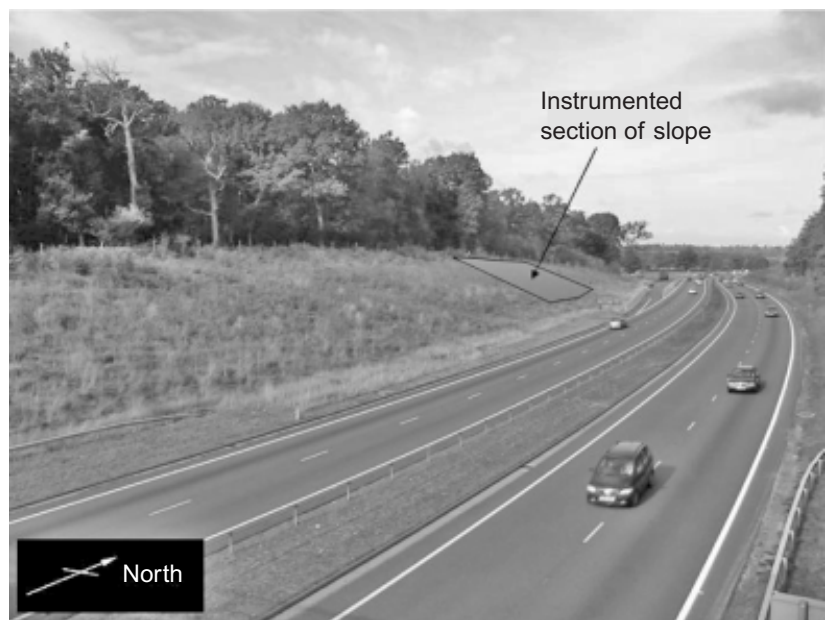

Fig. 2. Photograph of site

The current groundwater regime in the slope is effectively hydrostatic below the groundwater level. This indicates that, within the near-surface zone being monitored, any negative excess pore pressures induced by unloading as a result of excavating the cutting have substantially dissipated.

The vegetation is primarily rough grass and herbs with a few small shrubs less than $0.5 \mathrm{~m}$ high. The grass and herbs were initially mowed periodically to help the development of shrubs planted on the slope, but have remained uncut since October 2002. Mature beech, oak and silver birch trees fringe the top of the slope.

The London Clay is predominantly a stiff grey clay, but contains several bands of silty clay up to $50 \mathrm{~mm}$ thick and bands of large flints. The weathered London Clay is spatially very variable, changing from a stiff orange brown clay to a clayey silt over small distances and depths, similar to the description given by Perry et al. (2000). The permeability, unit weight and plasticity index of the London Clay at the site are summarised in Table 1. The saturated vertical permeability was obtained from tests on undisturbed samples from depths of $0.5,1.0,1.5,2.0$ and $3.0 \mathrm{~m}$ carried out at effective confining pressures of $10,15,20,25$ and $35 \mathrm{kPa}$ in the triaxial apparatus. Estimates of the in situ permeability, obtained from bailing out tests carried out in April 2003 in hand-augered boreholes $3 \mathrm{~m}$ deep, were typically one to two orders of magnitude larger owing to the effects of anisotropy and fabric (including silt partings and fissures) not fully captured in the triaxial samples. The dry unit weight was measured from undisturbed samples obtained from $0.5 \mathrm{~m}$ depth for both the weathered and unweathered clays.

Relationships between soil water content and suction for both the drying and wetting of (undisturbed) samples of London Clay have been published by Croney (1977), and are reproduced in Fig. 4. Fig. 4(a) shows the full set of data obtained by Croney (1977) plotted on a log scale for

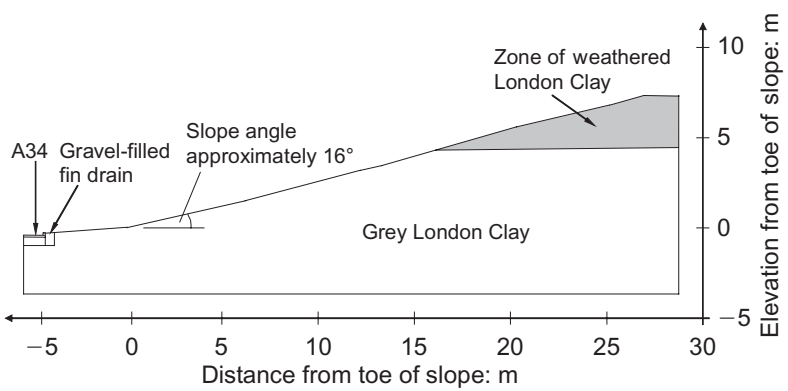

Fig. 3. Cross-section 
Table 1. Permeability, unit weight and plasticity index of grey and weathered London Clay at the Newbury test site

\begin{tabular}{|c|c|c|c|c|}
\hline \multirow[t]{2}{*}{ Property } & \multicolumn{2}{|c|}{ Grey London Clay } & \multicolumn{2}{|c|}{ Weathered London Clay } \\
\hline & Range & Average & Range & Average \\
\hline $\begin{array}{l}\text { Saturated vertical permeability } \\
\text { from triaxial tests: } \mathrm{m} / \mathrm{s}\end{array}$ & $3.9 \times 10^{-11}$ to $6.6 \times 10^{-10}$ & $2 \cdot 3 \times 10^{-10}$ & $5.0 \times 10^{-10}$ to $1.6 \times 10^{-9}$ & $8.7 \times 10^{-10}$ \\
\hline $\begin{array}{l}\text { Saturated permeability from } \\
\text { borehole bail-out tests: } \mathrm{m} / \mathrm{s}\end{array}$ & $2 \cdot 3 \times 10^{-9}$ to $4.4 \times 10^{-9}$ & $3.7 \times 10^{-9}$ & $3 \cdot 6 \times 10^{-8}$ to $5 \cdot 0 \times 10^{-8}$ & $4.3 \times 10^{-8}$ \\
\hline Dry unit weight, $\gamma_{\mathrm{d}}: \mathrm{kN} / \mathrm{m}^{3}$ & $13 \cdot 2$ to $15 \cdot 2$ & $14 \cdot 6$ & $13 \cdot 2$ to $16 \cdot 2$ & $16 \cdot 0$ \\
\hline Plasticity index, $I_{\mathrm{D}}: \%$ & $32 \cdot 5$ to $36 \cdot 4$ & $34 \cdot 8$ & $31 \cdot 7 *$ & $31 \cdot 7 *$ \\
\hline
\end{tabular}

* Only one of five samples tested for the weathered London Clay exhibited plasticity, the remainder were a silt.

suction; Fig. 4(b) shows the same data plotted up to a typical plant wilting point of $\mathrm{pF} 4 \cdot 2$ or $1500 \mathrm{kPa}$ (Kabat \& Beekma, 1994) on a linear scale that more clearly shows the rapid increase in suction that occurs as the soil dries.

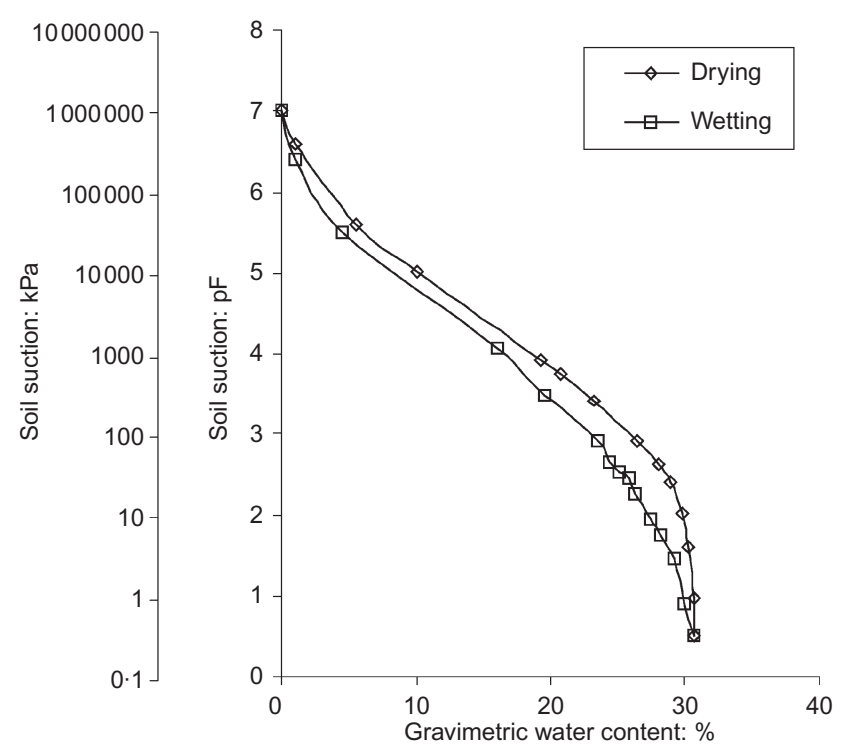

(a)

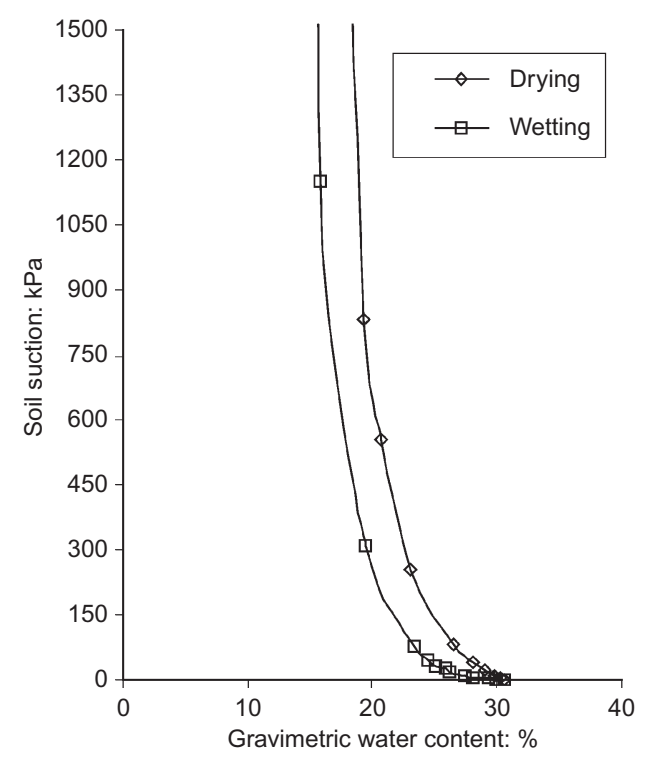

(b)

Fig. 4. Graphs of gravimetric water content against suction for undisturbed samples of London Clay (redrawn from Croney, 1977): (a) plotted on a log scale of suction; (b) plotted onto a linear scale of suction up to a typical plant wilting point of $1500 \mathrm{kPa}$
Vegetation will remove water from the soil profile when evapotranspiration is greater than rainfall, and during the summer the soil near the surface will begin to dry out. Intact clay peds will remain saturated even at quite high suctions owing to their small pore size. However, larger pores and fissures - especially near the surface-will desaturate at lower suctions.

\section{INSTRUMENTATION}

The site was instrumented to monitor the soil water content, pore water pressure, soil temperature, the free water surface, rainfall, runoff and climatic data required to estimate evapotranspiration.

Figure 5 shows the layout of the instrumentation. Arrays of time domain reflectrometry (TDR) probes for measuring soil water content, flushable vibrating wire piezometers, water filled tensiometers and equitensiometers were installed in four groups spaced $6 \mathrm{~m}$ apart down the slope. The sensors were installed at depths between $0.3 \mathrm{~m}$ and $3.5 \mathrm{~m}$, at intervals of $0.3 \mathrm{~m}$ or $0.5 \mathrm{~m}$. Table 2 summarises the sensor types and the depths at which they were installed.

Each sensor was installed into its own hole, which was hand-augered to a diameter slightly larger than the body of the sensor. The piezometer, equitensiometer and tensiometer ceramics were pushed into a stiff speswhite kaolin paste that had been placed at the base of the hole, to transmit suction effectively from the soil to ceramic of the sensor. A $20 \mathrm{~cm}$ depth of dry bentonite powder was used to form a plug above the instrument, before the hole was backfilled either with a stiff slurry mixed from bentonite and the extracted London Clay (shallow installations) or cement bentonite grout (deep installations). Only one sensor was installed in each hole, to minimise the possibility of errors due to an imperfect seal.

Rainfall at the site was recorded using two gauges in case of instrument failure. A climate station was placed on the slope to record air temperature, humidity, wind speed, solar radiation and soil temperature at $30 \mathrm{~cm}$ depth. Except for the soil temperature, these parameters were used to estimate potential evapotranspiration using the Penman-Monteith method (Allen et al., 1998).

Surface runoff together with interflow (i.e. flow of water through the topsoil) was measured using an interceptor drain cut across the face of the slope. The interceptor drain was $6 \mathrm{~m}$ long and $35 \mathrm{~cm}$ deep, dug through the topsoil into the top of the undisturbed London Clay. A slotted drainpipe with gravel packing channelled water into a stilling tank to allow silt to settle out, and thence into a tipping bucket flow gauge (Unidata Ltd, Sheffield) capable of measuring up to $15 \mathrm{l} / \mathrm{min}$.

All of the above sensors were connected to a Campbell Scientific CR10X data logger with a GSM modem connection, powered by a $12 \mathrm{~V}$ car battery recharged by a $10 \mathrm{~W}$ 


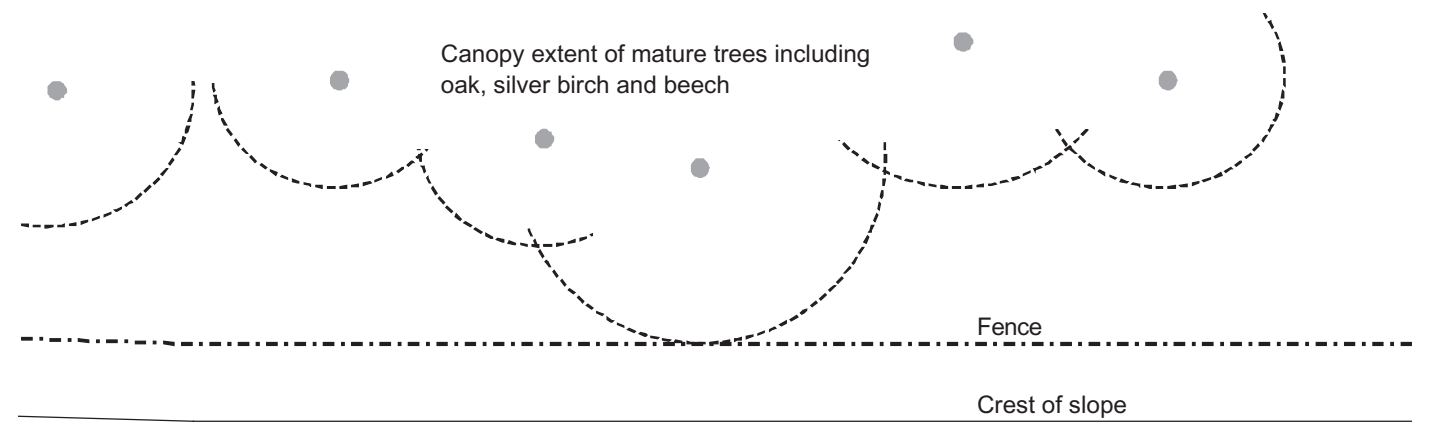

Datalogger and

climate station

(IP)

RG
A

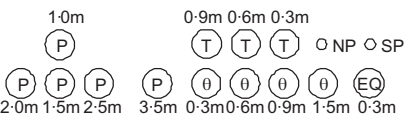

\begin{tabular}{ll|}
\hline P & Piezometer \\
$T$ & Tensiometer \\
$\theta$ & ThetaProbe \\
EQ & Equitensiometer \\
NP & Neutron probe access tube \\
SP & Slotted tube \\
TP & Soil temperature probe \\
RG & Rain gauge
\end{tabular}

D P P P T ONP $1.0 \mathrm{~m} 1.5 \mathrm{~m} \mathrm{2.5m} \mathrm{0.3m} \mathrm{0.6m} \mathrm{oSP}$

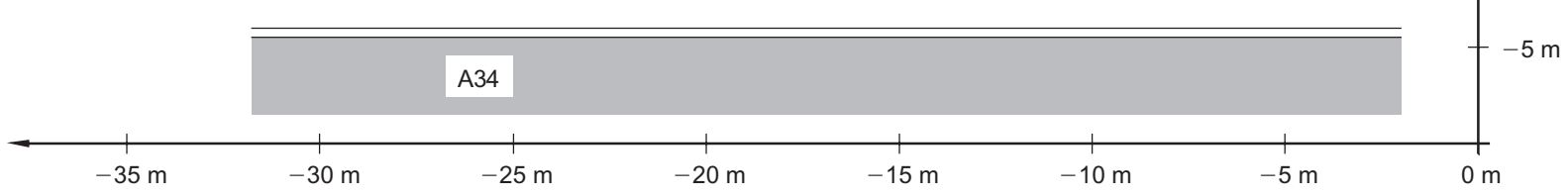

Fig. 5. Plan of site showing layout of instrumentation

Table 2. Summary of soil suction and water content sensors installed

\begin{tabular}{|c|c|c|c|c|}
\hline Measurement & Type of instrument & Quantity and depths & Measuring range/accuracy & Source/references \\
\hline Soil suction & Tensiometer & $\begin{array}{l}10 \text { no., depths of } 0 \cdot 3,0.6 \text {, } \\
0.9 \mathrm{~m}\end{array}$ & Matric suction up to $90 \mathrm{kPa}$ & $\begin{array}{l}\text { Delta-T Devices Ltd, } \\
\text { Cambridge, UK }\end{array}$ \\
\hline $\begin{array}{l}\text { Soil suction/pore water } \\
\text { pressure }\end{array}$ & Flushable piezometer & $\begin{array}{l}16 \text { no., depths of } 1 \cdot 0,1 \cdot 5, \\
2 \cdot 0,2 \cdot 5,3 \cdot 0,3 \cdot 5 \mathrm{~m}\end{array}$ & $\begin{array}{l}\text { Pore pressure between } 300 \text { and } \\
-90 \mathrm{kPa}\end{array}$ & $\begin{array}{l}\text { Soil Instruments Ltd, } \\
\text { Uckfield, UK }\end{array}$ \\
\hline Soil suction & Equitensiometer & 3 no., all at $0.3 \mathrm{~m}$ depth & $\begin{array}{l}\text { Matric suction up to } 1500 \mathrm{kPa} \text {, } \\
\text { over } 100 \mathrm{kPa} \text { accuracy } \pm 5 \% \text { of } \\
\text { reading }\end{array}$ & $\begin{array}{l}\text { Delta-T Devices Ltd, } \\
\text { Cambridge, UK }\end{array}$ \\
\hline Soil water content & TDR 'ThetaProbe' & $\begin{array}{l}8 \text { no., depths of } 0 \cdot 3,0 \cdot 6,0 \cdot 9 \\
1.5 \mathrm{~m}\end{array}$ & $\begin{array}{l}\text { Volumetric water content, } \\
0-50 \%\end{array}$ & $\begin{array}{l}\text { Delta-T Devices Ltd, } \\
\text { Cambridge, UK }\end{array}$ \\
\hline
\end{tabular}


solar panel. The data were logged at $10 \mathrm{~min}$ intervals and recorded as hourly averages, commencing in October 2002.

Aluminium access tubes for a neutron probe were installed to enable point measurements of water content adjacent to the logger sensors. A Wallingford neutron probe (Bell, 1987), calibrated against samples for which the water content was determined gravimetrically, was used to measure soil water profiles at approximately monthly intervals. Finally, four $50 \mathrm{~mm}$ diameter slotted plastic tubes were installed to act as observation wells at intervals down the slope to locate the position of the free water surface. The auger holes for the instruments and observation tubes provided a large number of soil samples from which gravimetric water contents were obtained.

\section{WATER BALANCE}

In the absence of artificial recharge or irrigation, water may enter the soil through the ground surface from rainfall and leave as a result of evapotranspiration by plants. For the zone of major seasonal wetting and drying at the slope surface, the full water balance may be written (after Blight, 2003) as

$$
\sum(R-\mathrm{RO})-\sum \mathrm{ET}+S-\mathrm{RE} \approx 0
$$

where $R$ is the rainfall, RO is the runoff, ET is the actual evapotranspiration, $S$ is the change in stored water within the soil, and RE is the net recharge from the surrounding soil. Rainfall is simple to measure, and although it can be very site specific, long records are available for the UK. Runoff is likewise site specific but measurable. Evapotranspiration is a function of the interactions between the elements of the plant-soil-atmosphere system. It depends on plant type, climate, soil characteristics and soil moisture conditions, and is more difficult to quantify owing to the variability of climate, soil and plant types. A simplified approach is to define a standard crop and soil condition so that evapotranspiration is then a function only of climate. This is known as the reference crop or potential evapotran- spiration, typical of that from a well-watered short green crop, such as $10-15 \mathrm{~cm}$ long healthy grass.

Potential evapotranspiration can be estimated with reasonable confidence using the Penman-Monteith equation (Allen et al., 1994), which is based on the energy available to change liquid water into water vapour and the vapour gradient from the evaporating surface to the atmosphere. Daily totals and monthly averages of potential evapotranspiration (PET) calculated using the climate data from the Newbury site are shown, and the latter compared with data for Southampton averaged over the period 1961-1990, in Fig. 6. The potential evapotranspiration at Newbury varied from almost zero in winter to a peak of $4.3 \mathrm{~mm} /$ day in July 2003, with significant daily fluctuations. The monthly averages were generally some $20-30 \%$ lower than the longterm data for Southampton because the slope at Newbury faces east and is in shade in the mid/late afternoon.

In the context of an investigation into the effect of vegetation on slope stability and behaviour, the purpose of a water balance calculation is to estimate changes in soil water content, which are related to the change in the volume of water stored within the soil, $S$. In agricultural science, $S$ is usually expressed as the soil moisture deficit (SMD), calculated in $\mathrm{mm}$ as a volume of water per unit area. A soil with zero SMD is at 'field capacity', that is, the equilibrium water content within a soil free to drain downward under gravity. Water is held in the soil by capillary action: hence field capacity is a function of pore size. For many soils, $\mathrm{SMD}=0 \mathrm{~mm}$ usually occurs $1-2$ days after rainfall and corresponds to a suction of about $\mathrm{pF} 2$ or $10 \mathrm{kPa}$ (Kabat \& Beekma, 1994). An intact clay soil would probably still be saturated at field capacity, but in a more structured material there is likely to be air present in the larger fissures and voids.

The soil moisture deficit changes dynamically in response to the inflows and outflows of water in the field, and if the water balance calculation covers too long a period of time, the results will be meaningless. For example, the climate of southern England generally has an annual net water surplus: that is, the total annual rainfall exceeds the total annual potential evapotranspiration (Table 3). However, more rain

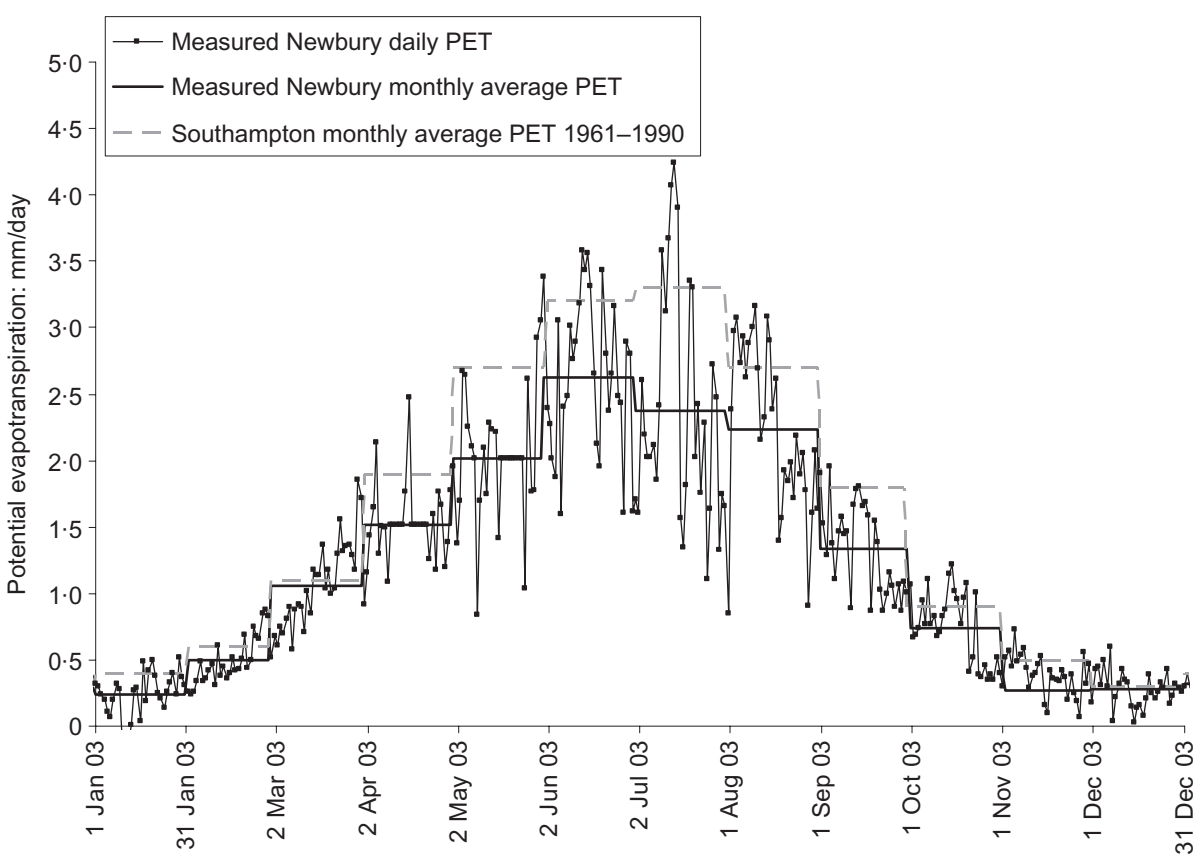

Fig. 6. Potential evapotranspiration for Newbury site calculated using measured weather parameters 
Table 3. Rainfall and potential evapotranspiration for the Newbury site, 2003

\begin{tabular}{l|c|c|c|c|c|c|c|c|c|c|c|c|c}
\hline & Jan & Feb & Mar & Apr & May & June & July & Aug & Sept & Oct & Nov & Dec & Total \\
\hline Rainfall: mm & $112 \cdot 0$ & $49 \cdot 0$ & $30 \cdot 1$ & $52 \cdot 1$ & $65 \cdot 8$ & $54 \cdot 9$ & $56 \cdot 8$ & $20 \cdot 2$ & $\begin{array}{r}10 \cdot 1 \\
39 \cdot 9\end{array}$ & $\begin{array}{r}50 \cdot 1 \\
22 \cdot 9\end{array}$ & $\begin{array}{r}135 \cdot 8 \\
11 \cdot 7\end{array}$ & $\begin{array}{r}86 \cdot 9 \\
8 \cdot 7\end{array}$ & $\begin{array}{r}723 \cdot 8 \\
467 \cdot 2\end{array}$ \\
\hline
\end{tabular}

falls in the winter months than in the summer, but potential evapotranspiration is greatest in the summer. This leads to a significant water surplus in the winter months, resulting in runoff, and a water deficit during the summer, which may lead to the vegetation becoming stressed. In the latter case, the actual rate of evapotranspiration is likely to fall below the potential evapotranspiration calculated using the Penman-Monteith equation, because a condition is reached whereby the residual soil moisture is not readily accessible by plants.

The low permeability of the clay means that, despite the likely establishment of a hydraulic potential gradient, the ability of the plants to remove water from the soil below the rooting zone (typically 0.6 to $0.9 \mathrm{~m}$ in clays: Allen et al., 1998; Greenwood et al., 2001) is limited. This is illustrated by data from the Newbury site shown in Figs 10, 12 and 18 and discussed in detail later: during early autumn 2003 , the top $0 \cdot 5-1 \cdot 0 \mathrm{~m}$ of soil experienced significant drying, and despite a suction gradient extending to a depth of several metres there was little change in the water content below $1.0 \mathrm{~m}$ depth. Taking the largest measured suction gradient (from $50 \mathrm{kPa}$ at $1 \mathrm{~m}$ depth to $0 \mathrm{kPa}$ at $4.5 \mathrm{~m}$ depth, in mid September 2003) and a high permeability for the London Clay $\left(1 \times 10^{-9} \mathrm{~m} / \mathrm{s}\right.$; Table 1$)$ gives an upward recharge rate according to Darcy's law of $0.04 \mathrm{~mm} /$ day. This is negligible in comparison with the potential evapotranspiration of $1.5 \mathrm{~mm} /$ day for the same period. Hence it is reasonable to ignore recharge from below the rooting zone in the water balance calculation (equation (1)) in comparison with the other inputs and outputs, giving

$$
\sum(R-\mathrm{RO})-\sum \mathrm{ET}+S \approx 0
$$

For the purposes of calculation, it might reasonably be further assumed that all of the rainfall $R$ infiltrates until the ground is at field capacity (i.e. the runoff RO is zero), after which all of the rainfall runs off (i.e. $\mathrm{RO}=R$ ).

Assuming that the vegetation is not stressed, the actual evapotranspiration (ET) is calculated by scaling the potential evapotranspiration (PET) calculated using the Penman-Monteith equation by a crop factor $K_{\mathrm{c}}$ specific to the vegetation type.

In calculating the actual evapotranspiration it is necessary to consider not only the total available water in the active root zone, TAW (i.e. that not bonded to the surface of the clay particles), but also the remaining readily available water, RAW (i.e. that which the plants can access without stress). Both RAW and TAW are expressed as volumes of water per unit area within the zone of drying, and therefore have units of $\mathrm{mm}$, the same as the soil moisture deficit (SMD).

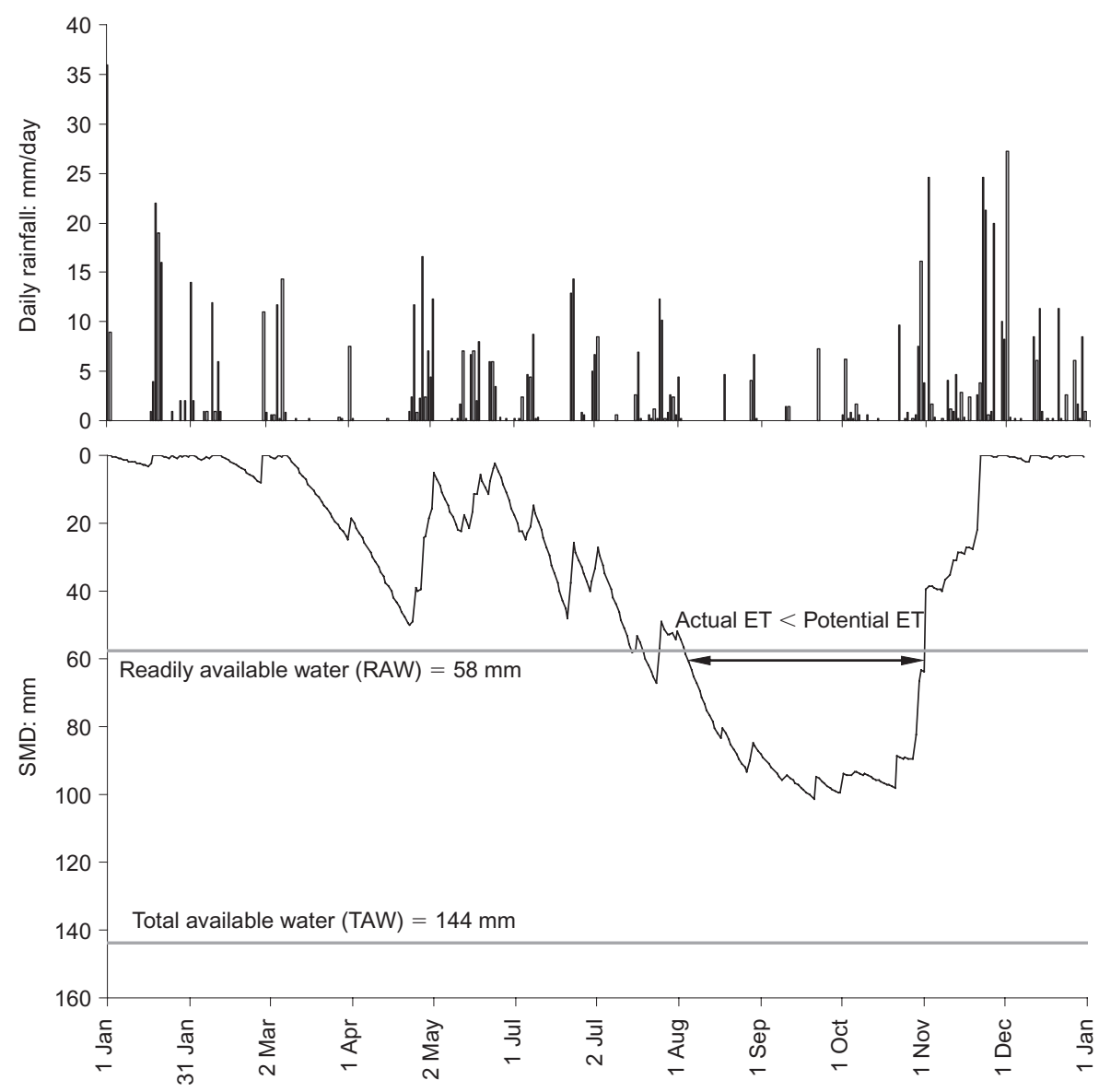

Fig. 7. Daily rainfall measured and soil moisture deficit calculated for Newbury site over year 2003 
While the SMD is less than the RAW, evapotranspiration can be assumed to occur at the potential rate for the actual crop (i.e. PET $\times K_{\mathrm{c}}$ ). When the SMD exceeds the RAW, evapotranspiration is assumed to fall below the potential rate in proportion to the ratio of non-readily available water (TAW - RAW) extracted: that is,

$$
\mathrm{ET}=\mathrm{PET} \times K_{\mathrm{c}} \quad \text { for } 0 \leqslant \mathrm{SMD} \leqslant \mathrm{RAW}
$$

and

$$
\mathrm{ET}=\mathrm{PET} \times K_{\mathrm{c}} \times \frac{\mathrm{TAW}-\mathrm{SMD}}{\mathrm{TAW}-\mathrm{RAW}} \quad \text { for } \mathrm{SMD} \geqslant \mathrm{RAW}
$$

This is the basis of the program CROPWAT (Clarke et al., 1998), which was used to calculate the water balance for the site at Newbury on the following basis.

(a) Recharge from the ground $(\mathrm{RE}=0)$ and runoff occur as already stated.

(b) The plant rooting depth for grass and herbs was taken as $800 \mathrm{~mm}$, and the water balance calculation was carried out for this depth of soil.

(c) At the start of the calculation period (1 January 2003), the $800 \mathrm{~mm}$ depth of soil was assumed to be at or above field capacity (i.e. SMD $=0$ ). This is reasonable given high rainfall during the preceding three months (October-December 2002).

(d) The crop factor for the long grass and herb vegetation on the slope at Newbury was taken as $K_{\mathrm{c}}=1.0$. (Typical values of $K_{\mathrm{c}}$ vary from 0.85 for short lawn grass to 1.2 for field crops such as wheat; Allen et al., 1998).

(e) Although a saturated clay may be $50 \%$ water (by volume), much of the water is chemically attached to the clay particles or held in small capillaries from which it is difficult for plants to extract. The total volume of water potentially available to the plants (TAW) was taken as $18 \%$ of the total soil volume: this is consistent with the values measured for a range of soils by Hall et al. (1977) and Jarvis \& Mackney (1979), and for a soil depth of $800 \mathrm{~mm}$ gives a TAW of $144 \mathrm{~mm}$. The TAW corresponds to the change in water up to the wilting point, typically a soil suction of about pF 4.2 or $1500 \mathrm{kPa}$ (Kabat \& Beekma, 1994).

$(f)$ The readily available water (RAW) is taken as the change in moisture up to the point where the vegetation

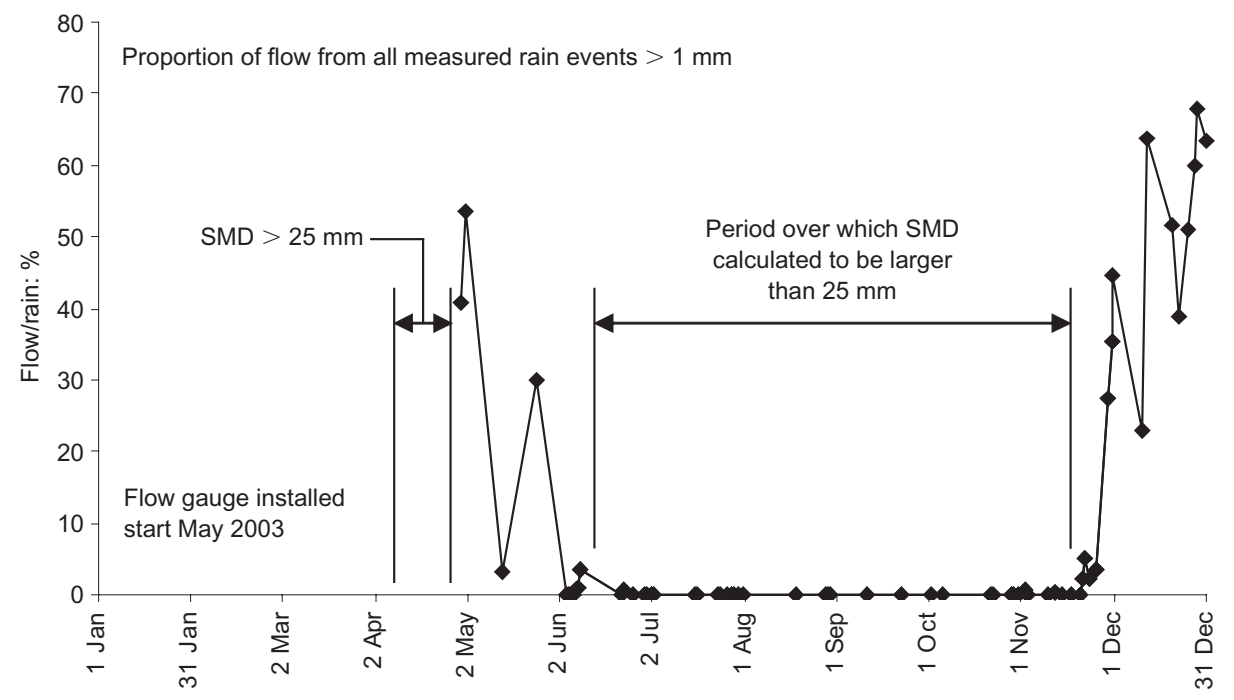

Fig. 8. Proportion of each rainfall event measured by flowgauge (graph is for 2003)

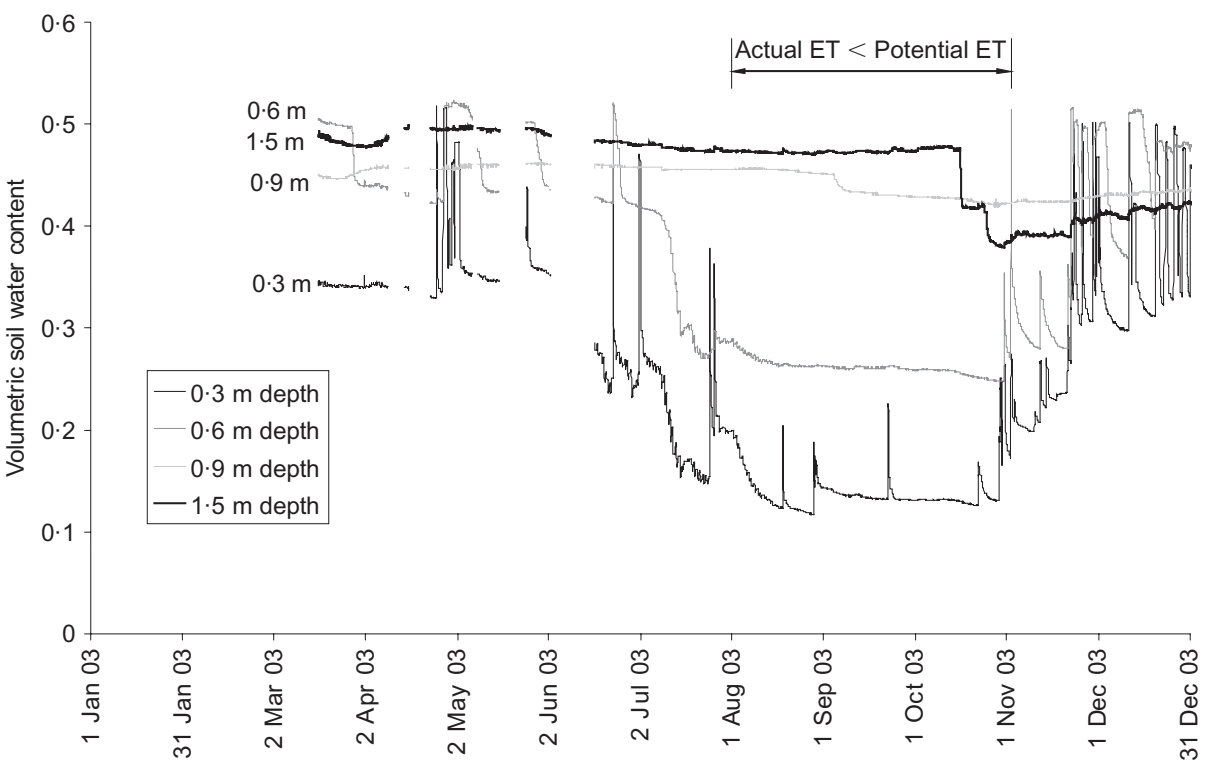

Fig. 9. Readings from TDR probes installed in weathered London Clay at instrument group A 


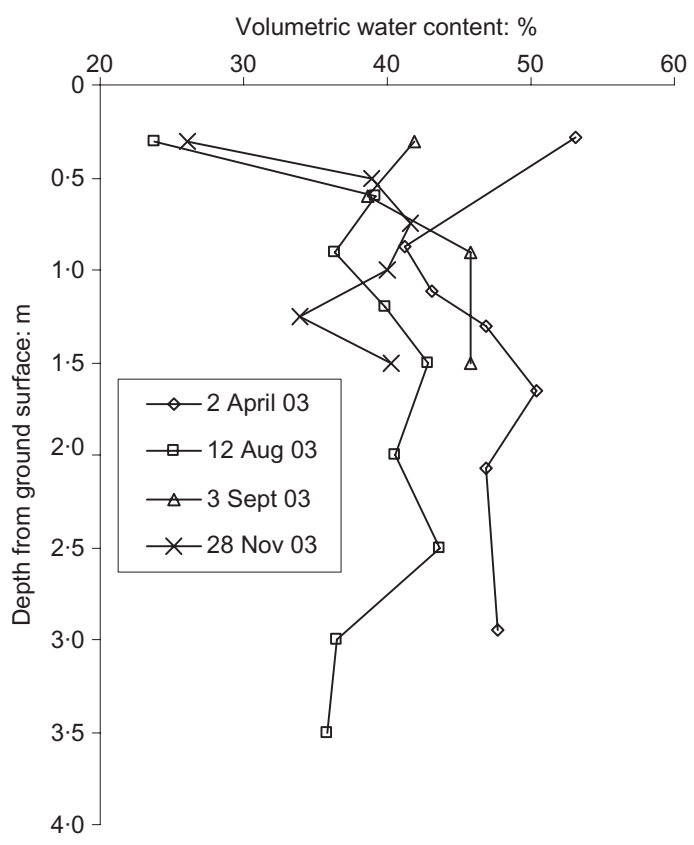

(a)

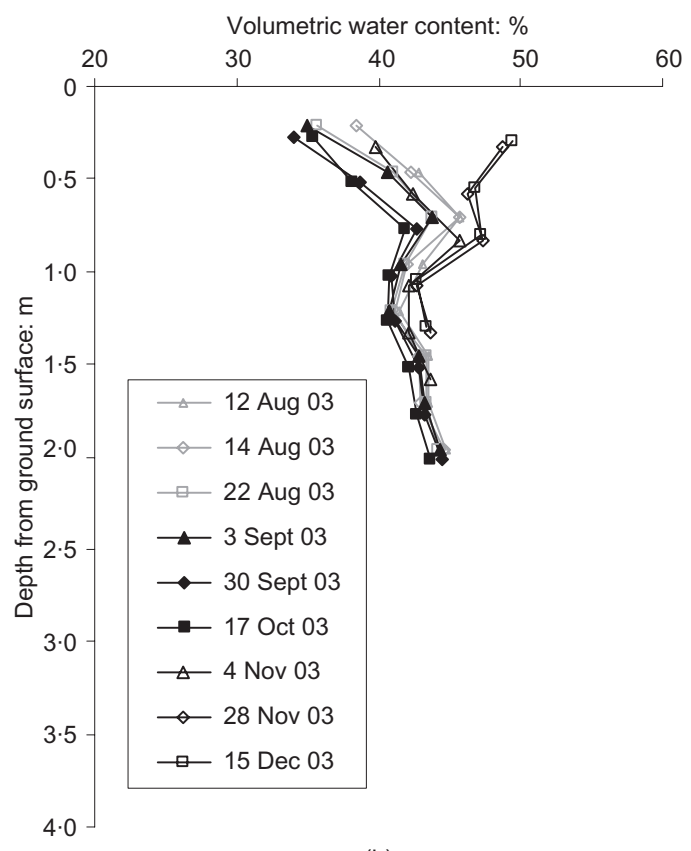

(b)

Fig. 10. Volumetric water content against depth for instrument group A: (a) soil samples taken to laboratory and oven-dried (converted from gravimetric to volumetric water content using average dry bulk density shown in Table 1); (b) neutron probe readings

starts to become stressed; this typically occurs at a soil suction of $\mathrm{pF} 2 \cdot 6-3 \cdot 0$ or $40-100 \mathrm{kPa}$ depending on the soil properties and the vegetation type (Kabat \& Beekma, 1994). Measurements made in the London Clay at Newbury indicate that the grass and herbs start to experience difficulty extracting water from the soil at about $45 \mathrm{kPa}$ (shown by the onset of large diurnal variations in observed suction, Fig. 16). Considering the suction/water content characteristic curve in Fig. 4(b), $45 \mathrm{kPa}$ suction occurs when the water content is reduced to $40 \%$ of the TAW (where the TAW corresponds to $10-1500 \mathrm{kPa}$ on the drying curve). Therefore the RAW was taken as $40 \%$ of the TAW, giving RAW $=0.4 \times 144 \mathrm{~mm}=58 \mathrm{~mm}$.
The soil moisture deficit was calculated using the above rules for the Newbury site for each day of 2003. This included an exceptionally hot dry summer period. The soil water balance (Fig. 7) suggests the development of a soil moisture deficit from mid February to late November. The calculated SMD exceeded the RAW from early August to late October, and reached a maximum of $101 \mathrm{~mm}$ in late September. This is consistent with the behaviour of the vegetation on the slope, which by early August had begun to turn brown owing to a lack of water.

In the winter months, low evapotranspiration and higher rainfall resulted in a calculated SMD close to zero. Rainfall during these periods could therefore not be stored in the soil profile and ran off. Fig. 8 shows the runoff and interflow measured by the flow gauge for individual rain events, starting in May 2003 when the flow gauge was installed at the site. The runoff events measured in April-May and December 2003 correspond with periods when CROPWAT calculated the SMD to be close, or equal, to zero. In addition, Fig. 8 shows that, for the period of the year in which the calculated SMD exceeded $25 \mathrm{~mm}$, no runoff was measured on the site (the largest daily rainfall event was $25 \mathrm{~mm}$; Fig. 7).

\section{MEASUREMENT OF SOIL WATER CONTENT AND SUCTION}

The water balance model for the soil-slope system was tested using the extensive measurements of soil water content and suction made at Newbury during 2003.

\section{Soil water content}

Volumetric soil water contents $\left(w_{\mathrm{vol}}=\right.$ volume of water $\div$ total volume) measured using the TDRs installed at the top of the slope in the $2.5 \mathrm{~m}$ thick layer of weathered London Clay at location A (Fig. 5) are shown in Fig. 9. Significant reductions in water content were measured at $0.3 \mathrm{~m}$ and $0.6 \mathrm{~m}$ depth between mid July to the end of October, reflecting the period when the calculated soil moisture deficit exceeded the limit of readily available water. Water content changes at $0.9 \mathrm{~m}$ and $1.5 \mathrm{~m}$ depth were smaller. Transient effects of rainfall events were noticeable at 0.3 and $0.6 \mathrm{~m}$, reflecting the saturation of the surface layers during rainfall and the subsequent redistribution of water into the ground.

Vertical profiles of volumetric water content based on oven-drying of samples taken at instrument group A during 2003 are shown in Fig. 10(a). These data were converted from gravimetric water contents $(w=$ mass of water $\div$ mass of soil solids) using the average value of dry unit weight given in Table $1\left(w_{\mathrm{vol}}=w \cdot \rho_{\mathrm{dry}} / \rho_{\mathrm{w}}\right.$. Note that the same dry density has been used to convert all four profiles; in reality the value may vary as the soil dries). Fig. 10(b) shows corresponding water content profiles measured at the same location using the neutron probe. In both cases, the most significant changes are over the top $1.0 \mathrm{~m}$. Below $1.0 \mathrm{~m}$ depth, the neutron probe suggests a fairly consistent water content of about $42 \%$ by volume, whereas the profiles obtained by oven-drying samples were more variable, probably because of the small distances (of up to about $2.5 \mathrm{~m}$ ) between the sampling locations and the spatially variable nature of the weathered London Clay.

Further down the slope at location $\mathrm{C}$, the topsoil and weathered clay is only $40 \mathrm{~cm}$ thick and the sensors are mainly in the unweathered grey London Clay. Fig. 11 shows the volumetric soil water contents measured by the TDR sensors, and Fig. 12 shows the volumetric water content profiles with depth from borehole sampling and neutron probe surveys. The changes in water content here are 


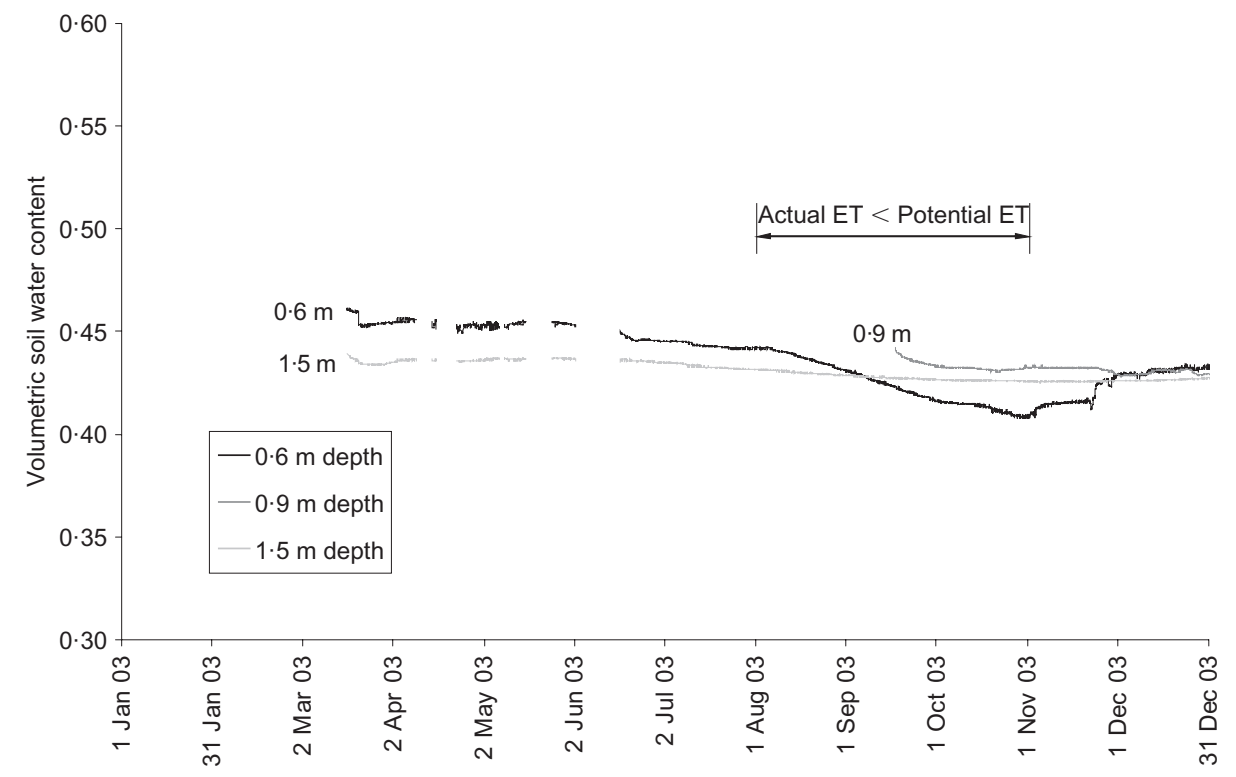

Fig. 11. Readings from TDR probes installed into grey London Clay at instrument group C

smaller than those measured at location A in the weathered London Clay (Figs 9 and 10). For example, at $0.6 \mathrm{~m}$ depth the reduction in volumetric water content over the summer measured by the TDRs was only $4 \%$ at $\mathrm{C}$ compared with $20 \%$ at A. Neutron probe data show a smaller difference at $0.6 \mathrm{~m}$, with $5 \%$ drying at $\mathrm{C}$ compared with $8 \%$ at A. Comparison of Fig. 12 with Fig. 10 confirms that the depth of significant summer drying is slightly less $(\sim 800 \mathrm{~mm}$ compared with $\sim 1000 \mathrm{~mm}$ according to the neutron probe data) in the grey London Clay than in the weathered material. The generally smaller amount of drying at $\mathrm{C}$ reflects the difficulty that the plant roots had in penetrating or removing water from the stiff intact clay peds and/or the likely groundwater flow regime of seepage out of the toe of the slope.

The measured water contents in the upper soil profile may be compared with the SMD calculated using CROPWAT, by noting that

$$
\Delta w_{\mathrm{vol}}=\frac{\Delta V_{\mathrm{w}}}{V_{\mathrm{t}}}=-\frac{\Delta \mathrm{SMD} \cdot A}{h \cdot A}=\frac{-\Delta \mathrm{SMD}}{h}
$$

where $h$ is the depth of the drying zone. SMDs determined from the neutron probe data (Figs 10(b) and 12(b)) and the TDR data at instrument group A (Fig. 9) on this basis, with $h=800 \mathrm{~mm}$ and $\Delta w_{\text {vol }}$ taken as the average over this depth and the wettest profile taken to correspond to $\mathrm{SMD}=0$, are compared in Fig. 13 with the SMDs calculated using CROPWAT. (The absence of a TDR probe at $0.3 \mathrm{~m}$ depth at instrument group $\mathrm{C}$ makes it difficult to calculate the drying from the TDRs at this location.)

In general, the match between the CROPWAT calculation and the neutron probe data is close. While the data from the TDR probes give a reasonable match to the CROPWAT calculation in the early part of the year (March-July 2003), during the summer the TDRs show a much greater extent of drying. Although located fairly close together on the slope, the samples taken from the auger holes for water content determination show that the neutron probe tube is installed predominantly in clay whereas the TDR probes are in clayey sandy silt. Both the total and readily available water would be expected to be slightly larger for a silt than for a clay, allowing a greater extent of soil drying by the vegetation. The water-holding capacity used in the CROPWAT calculation can be varied to account for this, but it does not fully explain the apparent discrepancy between the TDR and neutron probe data. The difference might be due to additional drainage processes in the silt not taken into account in the CROPWAT calculation, or the fact that the TDR probes respond to and represent a rather smaller volume of soil.

\section{Pore pressures and suctions}

Figure 14 shows data from vibrating-wire peizometers between 1.0 and $3.75 \mathrm{~m}$ deep at Group A at the top of the slope in the weathered clay. The winter of 2002-2003 was very wet, with $300 \mathrm{~mm}$ of rainfall in November and December 2002 resulting in positive pore water pressures being recorded at all instruments between December 2002 and March 2003. The summer of 2003 was unusually hot and dry. From May to September 2003 evapotranspiration was greater than rainfall, resulting in the development of a large soil moisture deficit and associated negative pore pressures. The highest suction recorded was $25 \mathrm{kPa}$ at $1.0 \mathrm{~m}$ depth in mid October 2003. Heavy rainfall during November and December 2003 infiltrated into the soil profile, increasing the water content and reducing the soil suction. However, at the end of December 2003, most of the group A piezometers still measured a suction and had not recovered to their January 2003 values.

Water-filled tensiometers at 0.3 and $0.6 \mathrm{~m}$ depth within the root zone at Group A recorded suctions that increased rapidly in June 2003 (Fig. 15). Tensiometers can only measure suctions of up to $90 \mathrm{kPa}$ before the water in the device is drawn into the surrounding soil and air enters the instrument. On refilling, the soil again removes the water, as indicated by the repeated vertical lines in Fig. 15. Suctions at $0.9 \mathrm{~m}$ took longer to increase and reached a maximum of only $65 \mathrm{kPa}$ in October 2003. Diurnal variations in pore pressure of up to $\pm 5 \mathrm{kPa}$ were recorded during the build-up of suction in the tensiometers, caused by the relaxation of vegetation water demand during the night. As the suction increases, further increases in suction yield less and less water, as indicated by the steepening of the SWCC curve (Fig. 4). Relaxation of water demand at night results in bigger diurnal cycles of suction, especially after about $45 \mathrm{kPa}$ (Fig. 16).

Data from the piezometers installed in Group $\mathrm{C}$ are shown in Fig. 16. The late-summer suctions are larger than at A, 

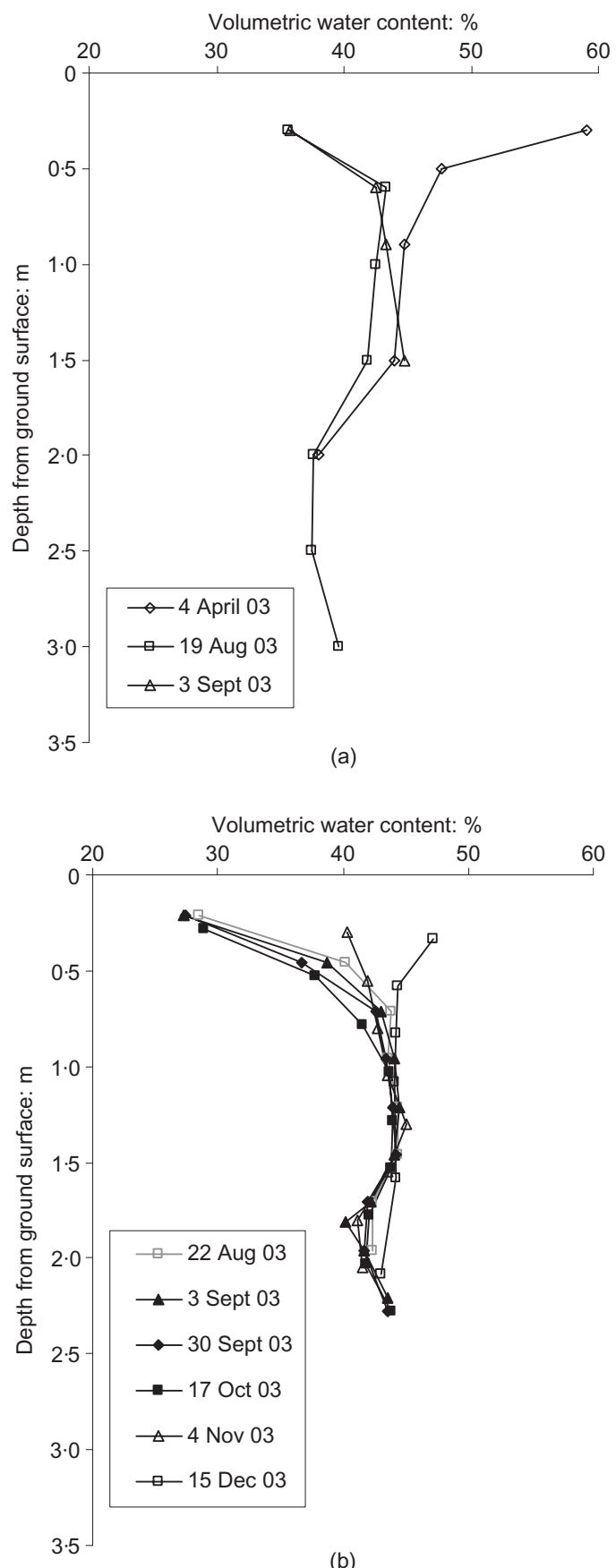

(b)

Fig. 12. Volumetric water content against depth for instrument group C: (a) soil samples taken to laboratory and oven-dried (converted from gravimetric to volumetric water content using average dry bulk density shown in Table 1); (b) neutron probe readings

exceeding $65 \mathrm{kPa}$ at $1.0 \mathrm{~m}$ depth between August and October. Suctions in excess of $25 \mathrm{kPa}$ were recorded for several weeks at $1.5 \mathrm{~m}$ and $2.0 \mathrm{~m}$ depth. Heavy rainfall during November and December caused an increase in water content and a corresponding decrease in soil suction. The sudden large changes in pore pressure at $1.0 \mathrm{~m}$ and $1.5 \mathrm{~m}$ depth are the result of rain filling tension cracks close to the instrument. Pore pressures at the end of December 2003 had not recovered to their January 2003 values owing to the particularly dry summer and the fact that the previous winter (to January 2003) had been exceptionally wet.

Observations of suctions near the surface (to $0.6 \mathrm{~m}$ depth) at $\mathrm{C}$ were made using water-filled tensiometers (Fig. 17). Suctions to the maximum recordable by the tensiometers (about $90 \mathrm{kPa}$ ) developed rapidly in June 2003 at $0.3 \mathrm{~m}$ depth and by the end of July at $0.6 \mathrm{~m}$ depth. Deeper piezometers recorded increasing suctions until November 2003. Suctions greater than $90 \mathrm{kPa}$ were recorded using an equitensiometer, which consists of a TDR sensor encapsulated in a fine ceramic with known moisture content-suction characteristics. This was installed at $0.3 \mathrm{~m}$ depth. Suctions greater than $70 \mathrm{kPa}$ were recorded during the period over which the calculated SMD was greater than the RAW (Fig. 7), with a maximum suction of $440 \mathrm{kPa}$ being measured in September 2003 (Fig. 17). However, the equitensiometer data are very sensitive to the water content-suction relationship of the ceramic, so these data should be treated as indicative only rather than quantitative.

The field measurements of pore water pressure and water content highlight a deficiency in the detail of the CROPWAT water balance model in the context of the current application. The gradual drying process in the summer is described well by CROPWAT, but during rapid re-wetting it assumes full redistribution of soil water at the end of each day. This does not allow for the low permeability of the clay, which prolongs the re-wetting process, especially for intact peds. CROPWAT assumes that any water in excess of zero SMD is redistributed or drains off the slope during the one-day time step calculation, which may not occur in reality. This is illustrated in Fig. 9, where the shallow TDR soil water content sensors show spikes following rainfall. These spikes reflect rapid increases in water content to saturation, which then returns to field capacity about 2 days after the rainfall.

Figure 18 shows the profiles with depth of maximum and minimum pore pressure measured by the piezometers and tensiometers in each of the four instrument groups. The (maximum) pore water pressures in early January 2003 were generally hydrostatic below a water table at most $0.5 \mathrm{~m}$ below the slope surface (note that the tensiometers had not yet been installed in January 2003). By late September the (minimum) pore water pressures were negative to at least $4 \mathrm{~m}$ depth, with the overall change in pore water pressure being greatest at the surface and decreasing non-linearly with depth. The high suctions $(>90 \mathrm{kPa})$ close to the surface correspond with the significant soil drying measured from 0 to $800-1000 \mathrm{~mm}$ depth (Figs 10 and 12). The extensive drying in the clay in this upper zone is caused by the direct removal of water by the plant roots, and the depth of the drying zone is therefore dependent on the ability of the roots to penetrate the clay.

Beneath this major drying zone, the suctions are smaller (Fig. 18), and the gradient denotes some upward movement of water (although for the purposes of the water balance calculation this was shown to be small, and consequently ignored). The reason why the high suctions close to the surface are not transmitted to the soil below the major drying zone is likely to be the low permeability of the clay, which is exacerbated by the high degree of drying of the soil that occurs at the surface. In a stiff clay, the vegetation therefore has limited ability to draw water from below its root zone.

The seasonal range of pore water pressures shown in Fig. 18 is similar to that determined by Walbancke (1976; replotted by Vaughan et al., 2004) from measurements in a number of grassed embankment and cutting slopes, where the largest suctions occurred over the top $2.0 \mathrm{~m}$ of soil and the maximum winter pore pressures in the same $2.0 \mathrm{~m}$ zone are hydrostatic from the slope surface.

\section{Relating the observed pore water pressures and soil} moisture contents

The envelope of maximum soil suction shown in Fig. 18 has been converted into a profile of water content with depth 


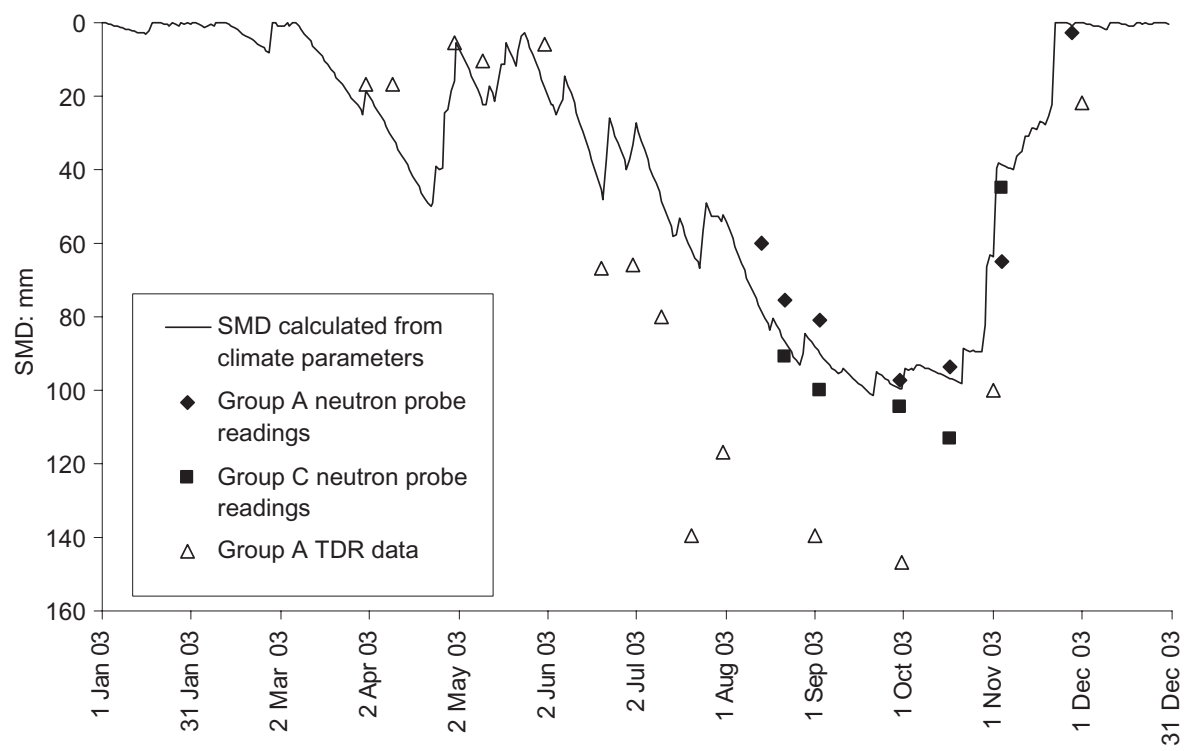

Fig. 13. Profile of daily soil moisture deficit obtained from CROPWAT plotted with measured drying taken from neutron probe readings and TDR data

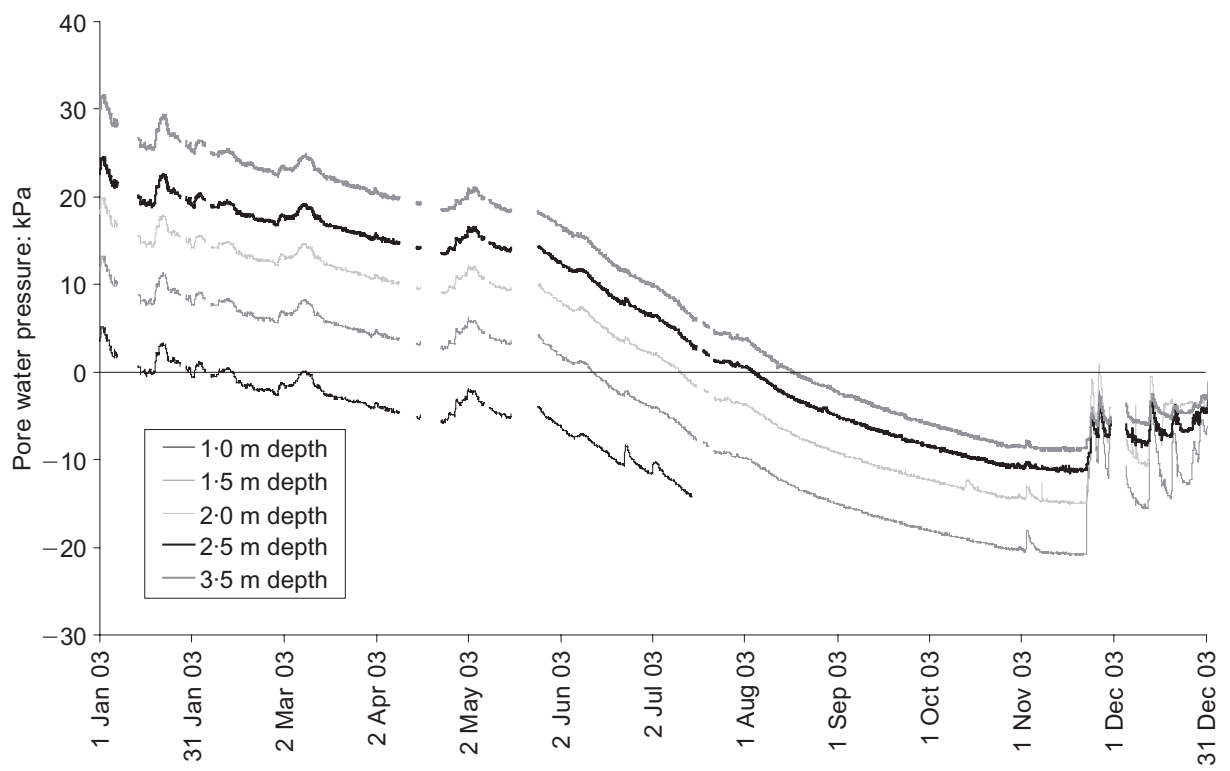

Fig. 14. Piezometer readings from instrument group A

using the soil water characteristic curve (SWCC) for the London Clay given in Fig. 4. This is plotted with the measured neutron probe water content profiles in Fig. 19. In making the calculation from the maximum soil suction to the corresponding volumetric water content profile, the following assumptions were made.

(a) The suction at $0 \cdot 3 \mathrm{~m}$ depth was that measured by the equitensiometer at Group $\mathrm{C}$ of $440 \mathrm{kPa}$. In the absence of any measurements above $0.3 \mathrm{~m}$ depth, the maximum suction is assumed to be $440 \mathrm{kPa}$.

(b) The drying curve shown in Fig. 4 was used, as the soildrying processes in July and August 2003 that give the maximum suction are rapid and reasonably continuous.

(c) The drying curve of the SWCC, which has been obtained in terms of gravimetric water content, is assumed to correspond to a total change of $18 \%$ in volumetric water content between field capacity $(-10 \mathrm{kPa})$ and wilting point $(-1500 \mathrm{kPa})$, the full width of the curve shown in Fig. 4(b). The $18 \%$ change in volumetric water content is consistent with the total available water (TAW) used in the CROPWAT calculation.

Saturated conditions are assumed to be represented by a uniform-with-depth water content of $46 \%$ : this is consistent with the wettest profile measured by the neutron probe.

The envelope of water content change given by the maximum suction profile correlates reasonably well with measured neutron probe data, particularly over the major drying zone.

\section{IMPLICATIONS FOR ASSESSMENT AND MODELLING OF SLOPE STABILITY}

In terms of the stability of the slope, it is clear that rough grass and herb cover does not necessarily generate sufficient soil drying in the summer months for soil suctions to be be retained into the winter and early spring when the low evapotranspiration and higher rainfall make slope stability most critical. However, the drying caused by the rough 


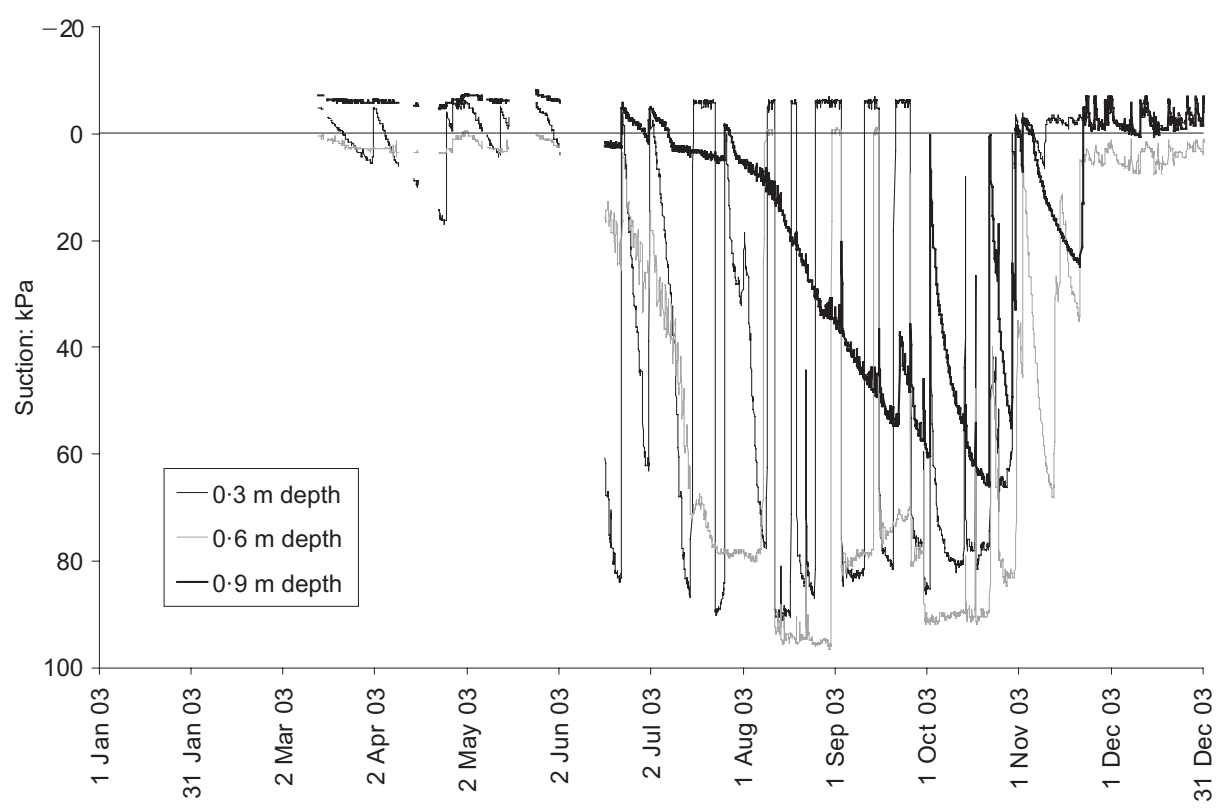

Fig. 15. Tensiometer readings from instrument group A

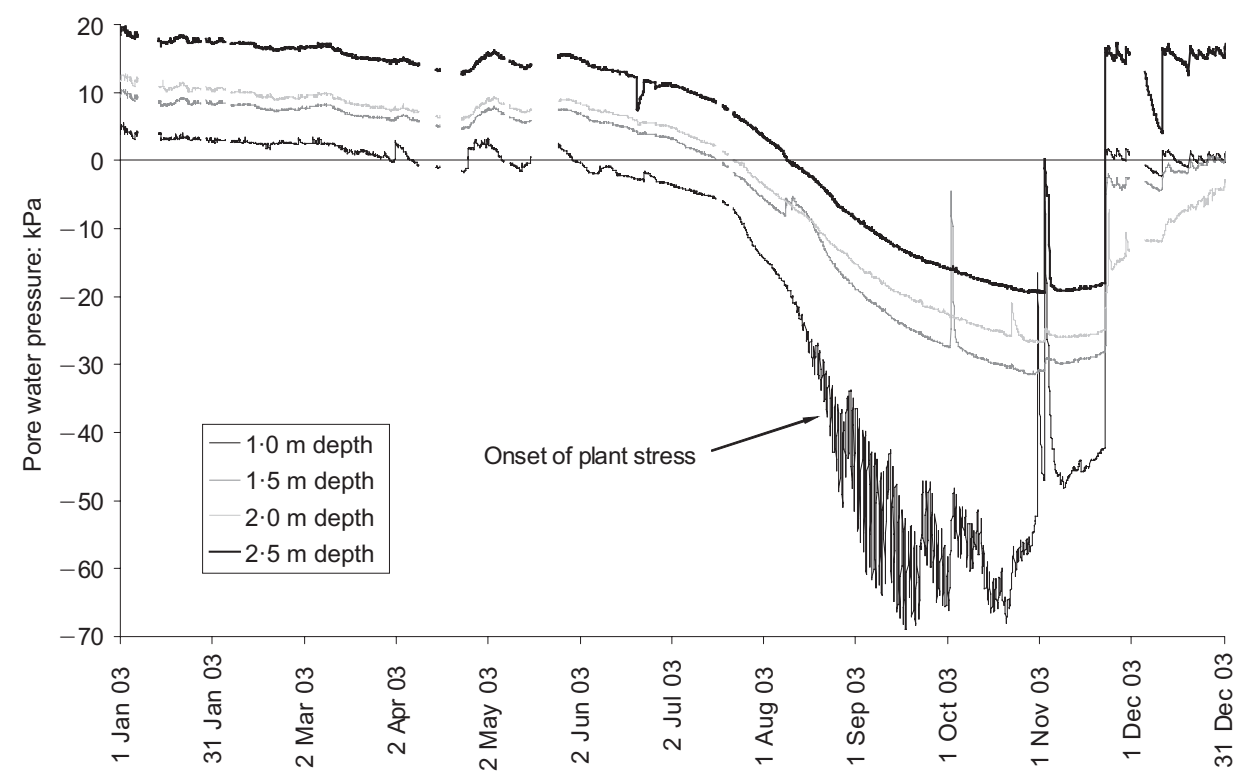

Fig. 16. Piezometer readings from instrument group $\mathrm{C}$

grass/herbs (and the prolonged time taken to re-wet the peds of the soil) does prevent critical winter and spring pore pressures being reached as often or for as long a period of time as when vegetation is absent from the slope. There are also other biomechanical benefits of vegetation, such as reinforcement of the soil by the plant roots, that will act to aid slope stability during the winter and spring months, and help to prevent erosion by surface runoff.

It is clear that the vegetation causes a large cyclic change in effective stress within the major drying zone (top $1.0 \mathrm{~m}$ depth of the profile) through the winter-summer-winter cycle for which data were presented. Recent work by Nyambayo et al. (2004), Take \& Bolton (2004), O'Brien et al. (2004) and Vaughan et al. (2004) has shown that the cyclic change in stress could promote progressive failure of the slope. The significant displacements caused by the cycles of shrink and swell cause damage to infrastructure and the need for regular maintenance and repair. With the possibility of drier summers and wetter winters as a result of climate change, it is likely that the problems of deep-seated progressive failure and serviceability problems within infrastructure slopes and embankments will worsen.

The work here has shown that a simple model of the plant-soil-atmosphere system based on the CROPWAT method can give a close estimate of the soil moisture deficit beneath a vegetated clay slope surface. The measured soil moisture deficit may then be linked to the pore water pressures using the SWCC curve for the clay. These results demonstrate the feasibility of creating a numerical model for a clay soil based on a water balance calculation in which the water inputs and outputs (rainfall infiltration and evapotranspiration) control the degree of saturation in the model soil, and the stress changes that take place are then calculated from the soil water content-suction relationship. Such an approach would enable the changes in water content and suction that occur in a clay soil with variability in the climate and water uptake by different types of vegetation to be calculated. The correct modelling of soil permeability 


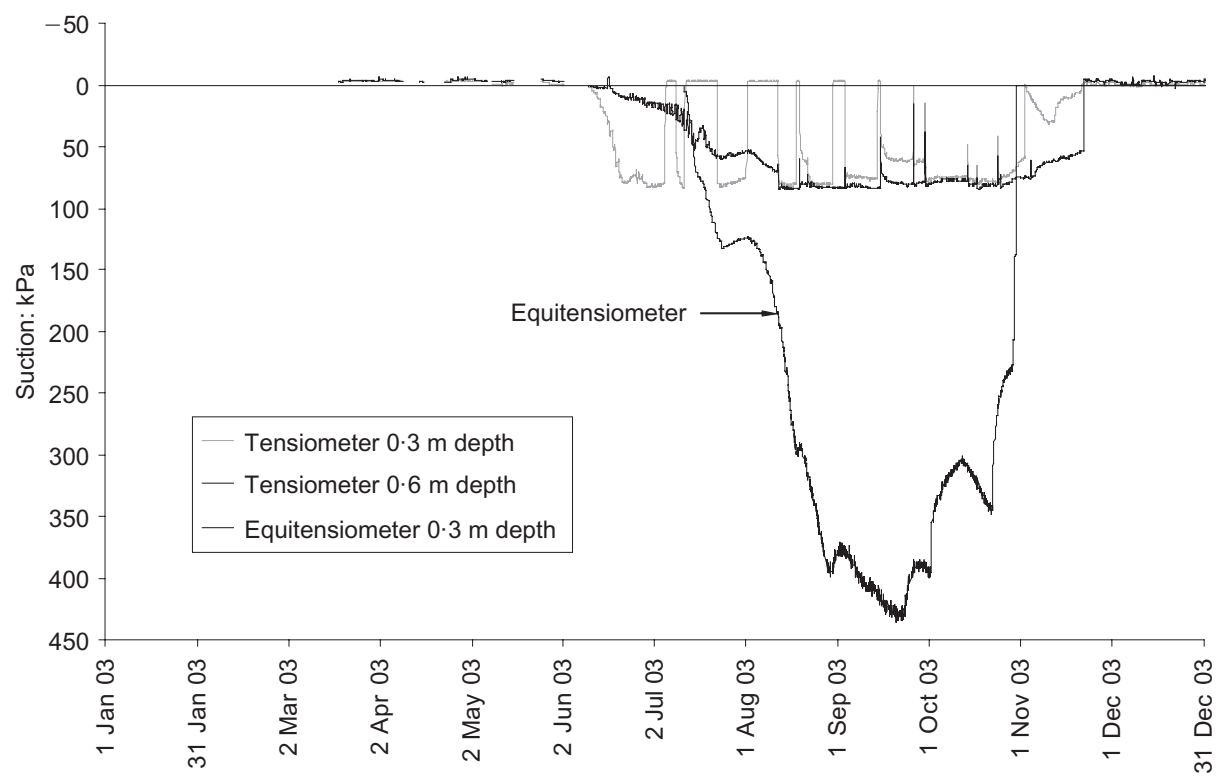

Fig. 17. Tensiometer and equitensiometer readings from instrument group C

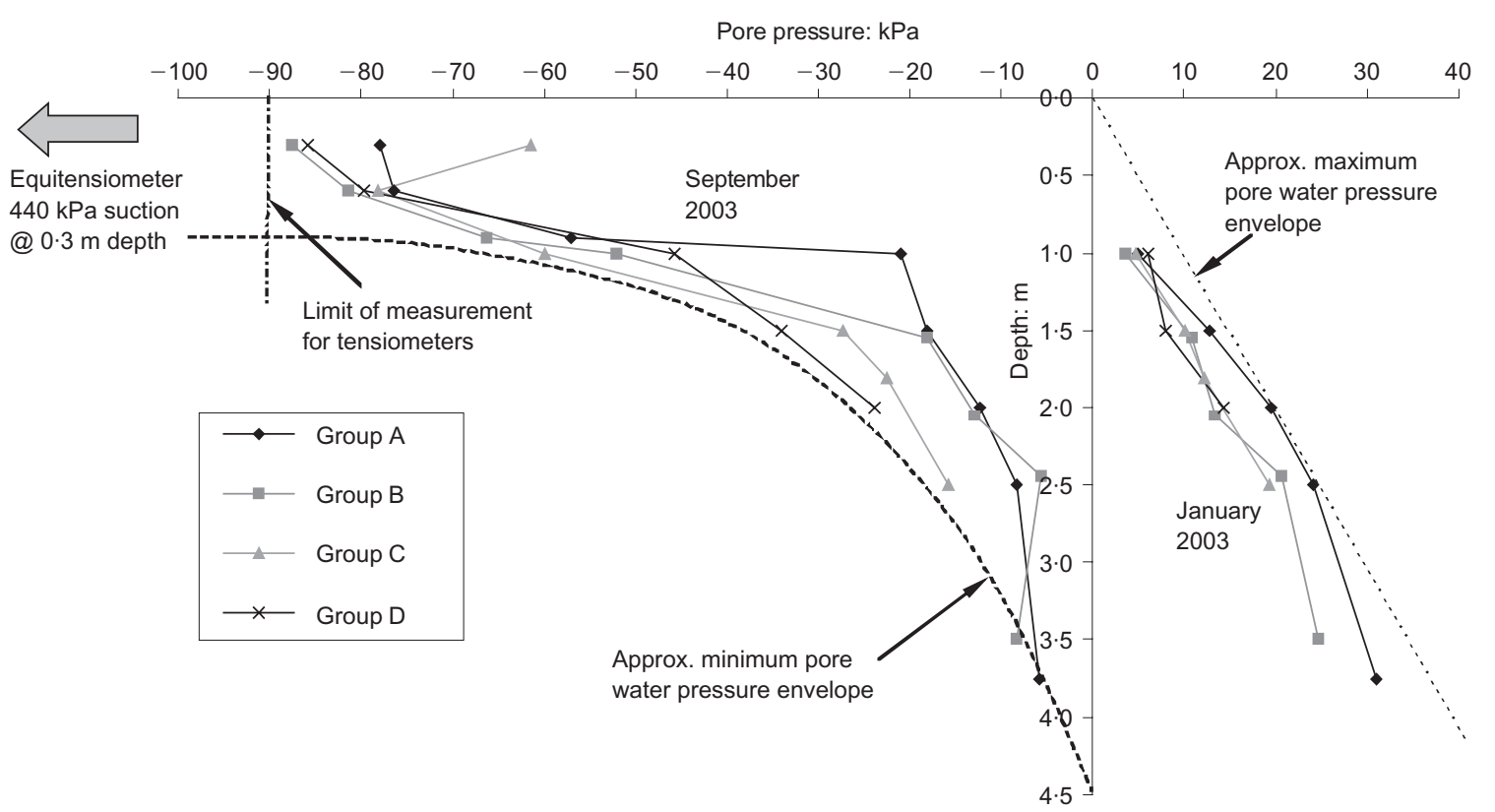

Fig. 18. Distribution of pore water pressure with depth

and flow should also improve the water balance (when compared with CROPWAT), with the delayed wetting up due to the low permeability of the intact lumps (peds) in a structured soil more accurately represented.

\section{CONCLUSIONS}

(a) The soil moisture deficit calculated by the water balance model CROPWAT was found to correlate well with the changes in soil water content measured in the slope throughout 2003. However, the early winter rewetting process is not so well modelled because CROPWAT assumes full redistribution of water each day. Measurement of site-specific climate parameters, incorporating the east-facing nature of the slope, was found to be important in the calculation of potential evapotranspiration.

(b) The water content measurements show that the vegeta- tion had caused a significant soil moisture deficit in the top $0.8-1.0 \mathrm{~m}$ depth of the clay by the late summer. Instruments installed within this zone measured a summer maximum profile of suction of about $450 \mathrm{kPa}$ at $0.3 \mathrm{~m}$ depth, decreasing to about $50 \mathrm{kPa}$ at $1.0 \mathrm{~m}$ depth. The extent and depth of soil drying were smaller in the grey London Clay at the toe of the slope, probably as a result of the natural seepage regime and/or the difficulty of plant roots penetrating into the stiff clay.

(c) The seasonal variation in water content in the London Clay below $1.0 \mathrm{~m}$ depth is small, typically $<4 \%$ by volume. In late summer, this small reduction in water content gave a suction varying between about $50 \mathrm{kPa}$ at $1.0 \mathrm{~m}$ depth and $0 \mathrm{kPa}$ at $4.5 \mathrm{~m}$ depth. The upward flow of water resulting from this suction gradient into the drying (root) zone at the slope surface is negligible in comparison with rainfall and evapotranspiration, and may be ignored in water balance calculations. In a clay 


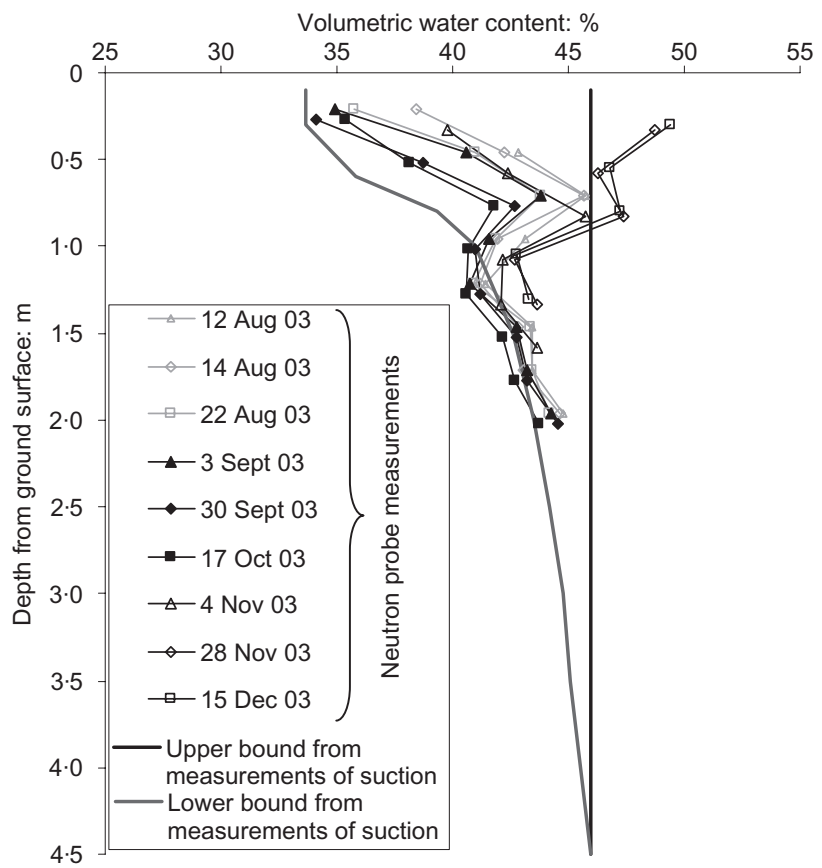

(a)

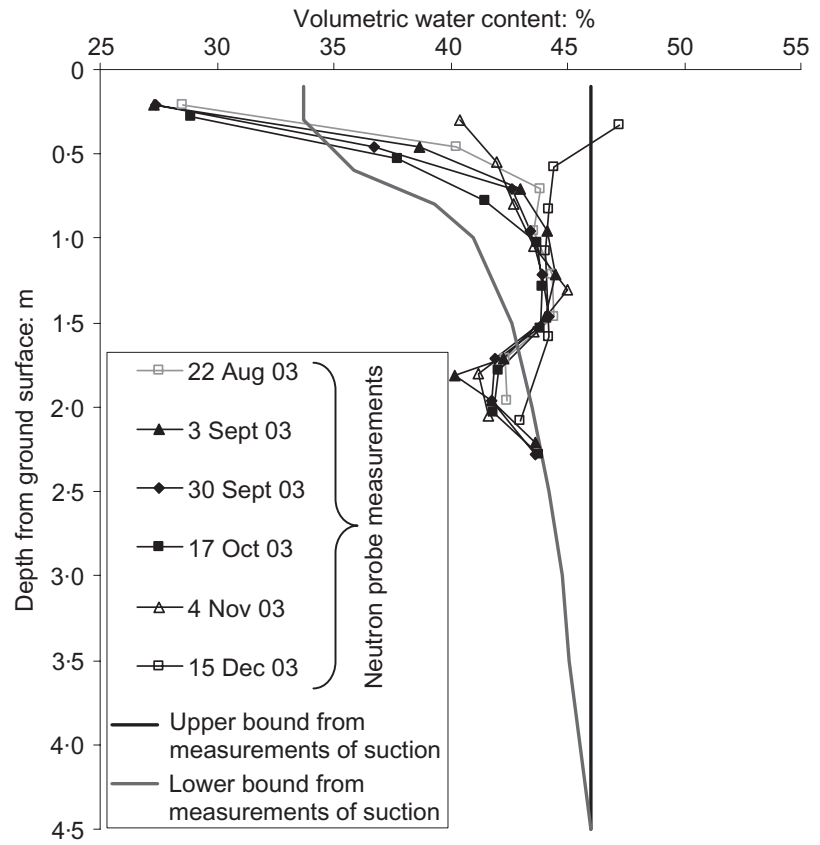

(b)

Fig. 19. Profiles of measured water content, with envelope of change in water content determined from measured suction profile: (a) instrument group $\mathrm{A}$; (b) instrument group $\mathrm{C}$

soil, the plants cause significant drying only within the rooting zone.

(d) The soil moisture deficit returned to zero through the winter months, meaning that the suctions generated by the rough grass and herb vegetation are unlikely to be able to improve slope stability in the winter and early spring.

(e) The measured water contents are reasonably consistent with measured suctions according to the laboratoryderived SWCC. This, together with the ability to calculate SMD with CROPWAT, demonstrates the feasibility of using a numerical model based on a surface flow boundary (representing infiltration and evapotranspiration) to predict the seasonal changes in soil water content and suction.

\section{ACKNOWLEDGEMENTS}

The work described in this paper was funded by EPSRC grant number GR/R72341/01. The authors are grateful to the Highways Agency for permission to use the slope at Newbury, and to John Perry and Martin Field of Mott MacDonald, who helped to make the arrangements with the Highways Agency and provided information on the construction and maintenance of the Newbury bypass. Thanks also go to Harvey Skinner, who assembled and maintained the datalogger systems.

\section{NOTATION}

A unit area

ET actual evapotranspiration

$h$ height of the drying (rooting) zone

$I_{\mathrm{D}}$ plasticity index

$K_{\mathrm{c}}$ crop coefficient

PET potential evapotranspiration

$\mathrm{pF}$ base $10 \log$ of the head of water in $\mathrm{cm}$

$R$ rainfall

RAW readily available water

$\mathrm{RE}$ recharge of water from surrounding soil

RO runoff

$S$ change in stored soil water

SMD soil moisture deficit

SWCC soil water characteristic curve

TAW total available water

$V_{\mathrm{w}}$ volume of water

$V_{t}$ total volume

$w$ gravimetric water content

$w_{\mathrm{vol}}$ volumetric water content

$\gamma_{\mathrm{d}}$ soil dry unit weight

$\rho_{\text {dry }}$ soil dry density

$\rho_{\mathrm{w}}$ density of water

\section{REFERENCES}

Allen, R. K., Smith, M., Perrier, A., \& Pereira, L. S. (1994). An update for the calculation of Reference Evapotranspiration. ICID Bulletin 43, No. 2, 35-92.

Allen, R. K., Pereira, L. S., Raes, D., \& Smith, M. (1998). Crop evapotranspiration: Guidelines for computing crop water requirements. Food and Agricultural Organization's Irrigation and Drainage Paper, No. 56.

Anderson, M. G., \& Kneale, P. E. (1980). Pore water pressure and stability conditions on a motorway embankment. Earth Surface Processes 5, No. 1, 37-46.

Andrei, A. (2000). Embankment stabilisation works between Rayners Lane and South Harrow Underground stations. Ground Engng, 33, No. 1, 24-26.

Barker, D. H. (1986). Enhancement of slope stability by vegetation. Ground Engng, 19, No. 3, 11-15.

Bell, J. P. (1987). Neutron probe practice, Institute of Hydrology report 19, 3rd edition. http://www.ceh.ac.uk/products/publications/documents/IH19NEUTRONPROBEPRACTICE.pdf

Blight, G. E. (2003). The vadose zone soil water balance and transpiration rates of vegetation. Géotechnique 53, No. 1, 55-64.

Blight, G. E. (1997). Interactions between the atmosphere and the earth. Géotechnique 47, No. 4, 715-767.

Biddle, P. G. (1983). Patterns of soil drying and moisture deficit in the vicinity of trees on clay soils. Géotechnique 33, No. 2, $107-126$. 
Biddle, P. G. (1998). Tree root damage to buildings. Wantage: Willowmead Publishing.

Coppin, N. J. \& Richards, I. G. (1990). Use of vegetation in civil engineering. London: Butterworth.

Crabb, G. I., West, G. \& O'Reilly, M. P. (1987). Groundwater conditions in three highway embankment slopes. Proc. 9th Eur. Conf. Soil Mech. Found. Engng, Dublin, 401-406.

Croney, D. (1977). The design and performance of road pavements. London: Her Majesty's Stationery Office.

Clarke, D., Smith, M. \& El-Askari, K. (1998). New software for crop water requirements and irrigation scheduling. ICID Bulletin 47, No 2 .

Driscoll, R. (1983). The influence of vegetation on the swelling and shrinking of clay soils in Britain. Géotechnique 33, No. 2, 93-105.

Greenwood, J. R., Vickers, A. W., Morgan, R. P. C., Coppin, N. J. \& Norris, J. E. (2001). Bioengineering: the Longham Wood Cutting field trial, CIRIA Project Report 81. London: Construction Industry Research and Information Association.

Greenwood, J. R., Norris, J. E. \& Wint, J. (2004). Assessing the contribution of vegetation to slope stability. Proc. Inst. Civ. Engrs Geotech. Engng 157, No. 4, 199-207.

Hall, D. G. M., Reeve, M. J., Thomasson, A. J. \& Wright, V. F. (1977). Water retention, porosity and density of field soils, Soil Survey Technical Monograph No. 9. Harpenden: Soil Survey of England and Wales.

Jarvis, M. G. \& Mackney, D. (1979). Soil survey applications, Soil Survey Technical Monograph No. 13. Harpenden: Soil Survey of England and Wales.

Kabat, P. \& Beekma, J. (1994). Water in the unsaturated zone, in Drainage principles and applications (ed. H. P. Ritzema), ILRI publication 16. Wageningen: International Institute for Land Reclaimation and Improvement, 383-434

MacNeil, D. J., Steele, D. P., McMahon, W. \& Carder, D. R. (2001).
Vegetation for slope stability, TRL Report 515. Crowthorne: Transport Research Laboratory.

Nyambayo, V. P., Potts, D. M. \& Addenbrooke, T. I. (2004). The influence of permeability on the stability of embankments experiencing seasonal cyclic pore water pressure changes. $A d-$ vances in Geotechnical Engineering: Proceedings of the Skempton Conference, Imperial College, London, Vol. 2, pp. 898-910.

O'Brien, A. S., Ellis, E. A., \& Russell, D. (2004). Old railway embankment clay fill: laboratory experiments, numerical modelling and field behaviour. Advances in Geotechnical Engineering: Proceedings of the Skempton Conference, Imperial College, London, Vol. 2, pp. 911-921.

Perry, J., Field, M., Davidson, W. \& Thompson, D. (2000). The benefits from geotechnics in construction of the A34 Newbury Bypass. Proc. Inst. Civ. Engrs Geotech. Engng 143, No. 2, 83-92.

Ridley, A., McGinnity, B., \& Vaughan, P. (2004a). Role of pore water pressures in embankment stability. Proc. Inst. Civ. Engrs Geotech. Engng 157, No. 4, pp. 193-198.

Ridley, A. M., Vaughan, P. R., McGinnity, B. \& Brady, K. (2004b). Pore pressure measurements in infrastructure embankments. $A d$ vances in Geotechnical Engineering: Proceedings of the Skempton Conference, Imperial College, London, Vol. 2, pp. 922-932.

Take, W. A. \& Bolton, M. D. (2004). Identification of seasonal slope behaviour mechanisms from centrifuge case studies. Advances in Geotechnical Engineering: Proceedings of the Skempton Conference, Imperial College, London, Vol. 2, pp. 992-1004.

Vaughan, P. R., Kovacevic, N. \& Potts, D. M. (2004). Then and now: some comments on the design and analysis of slopes and embankments. Advances in Geotechnical Engineering: Proceedings of the Skempton Conference, Imperial College, London, Vol. 1, pp. 241-290.

Walbancke, H. J. (1976). Pore pressures in clay embankments and cuttings. PhD thesis, Imperial College, London. 